University of Louisville ThinkIR: The University of Louisville's Institutional Repository

Electronic Theses and Dissertations

5-2019

\title{
Hybridity and political disorder : a mixed method approach to understanding the hybrid regime.
}

Bryce Jamison Kleinsteuber

University of Louisville

Follow this and additional works at: https://ir.library.louisville.edu/etd

Part of the Political Science Commons

\section{Recommended Citation}

Kleinsteuber, Bryce Jamison, "Hybridity and political disorder : a mixed method approach to understanding the hybrid regime." (2019). Electronic Theses and Dissertations. Paper 3190.

https://doi.org/10.18297/etd/3190

This Master's Thesis is brought to you for free and open access by ThinkIR: The University of Louisville's Institutional Repository. It has been accepted for inclusion in Electronic Theses and Dissertations by an authorized administrator of ThinkIR: The University of Louisville's Institutional Repository. This title appears here courtesy of the author, who has retained all other copyrights. For more information, please contact thinkir@louisville.edu. 


\title{
HYBRIDITY AND POLITICAL DISORDER: \\ A MIXED METHOD APPROACH TO UNDERSTANDING THE HYBRID REGIME
}

\author{
By \\ Bryce Jamison Kleinsteuber \\ B.A., University of Louisville, 2015 \\ Master of Arts \\ In Political Science \\ Department of Political Science \\ University of Louisville \\ Louisville, Kentucky
}

\begin{abstract}
A Thesis
Submitted to the Faculty of the

College of Arts and Sciences of the University of Louisville

In Partial Fulfillment of the Requirements

For the Degree of
\end{abstract}

May 2019 



\section{HYBRIDITY AND POLITICAL DISORDER: \\ A MIXED METHOD APPROACH TO UNDERSTANDING THE HYBRID REGIME PARADOX \\ By \\ Bryce Jamison Kleinsteuber \\ B.A., University of Louisville, 2015 \\ A Thesis Approved on}

April 09, 2019

by the following Thesis Committee:

Thesis Director

Dr. David Buckley

Dr. Jason Gainous

Dr. Blake Beattie 


\section{DEDICATION}

This thesis is dedicated to my fiancée

Sarah Marie Barnett

and my roommate

Shawn Michael Kiely,

both of whom have given me invaluable support throughout this project. 


\section{ABSTRACT \\ HYBRIDITY AND POLITICAL DISORDER:
A MIXED METHOD APPROACH TO UNDERSTANDING THE HYBRID REGIME PARADOX \\ Bryce Jamison Kleinsteuber}

April 9, 2019

This thesis focuses on two central questions; first, does regime hybridity lead to an increased propensity for political disorder; and second, what specific regime level characteristics are responsible for the increased propensity. The theoretical basis for this study is founded in the understanding that the duality of Hybrid regimes ensures that they receive neither the benefit of Authoritarian, coercive force nor Democratic plasticity and thus are unable to prevent political disorder. Therefore, during periods of political transition leaders in these regimes not only cannot prevent these events but may be incentivized to allow or even encourage certain events as a means for citizens to vent political frustration. Hybrid regimes are a topic central to comparative politics, yet work is only now beginning to study specific facets and characteristics of these regimes. Thus, scholars are just beginning to explore hybrid regime characteristics and how they impact critical political activities, is especially true concerning a topic of utmost importance, political disorder. The paper utilizes the PRIO data on Urban Social Disorder to first verify that Hybrid regimes suffer from an increased propensity for political disorder, before proceeding to a case study on Algeria. This case study 
focuses on journalistic accounts of political disorder. By employing a content analysis of Newspaper articles, the causal mechanism at play is highlighted. 


\section{TABLE OF CONTENTS}

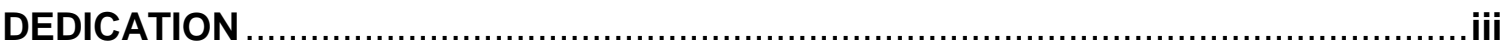

ABSTRACT

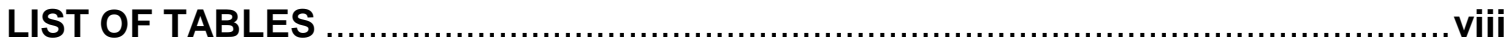

LIST OF FIGURES

INTRODUCTION

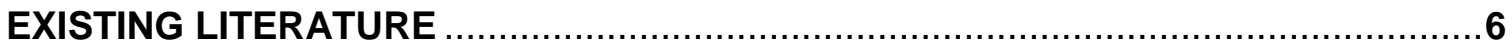

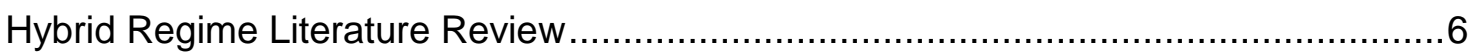

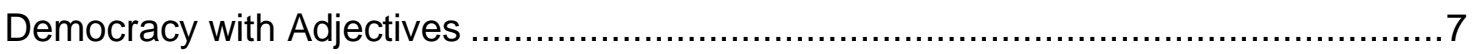

Beyond Democracy

The Resurgence of Hybrid Regimes ……………......................................12

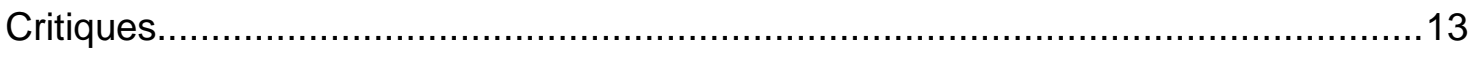

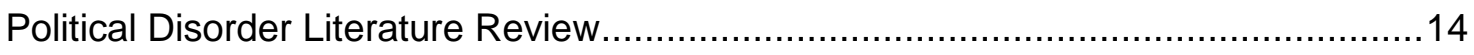

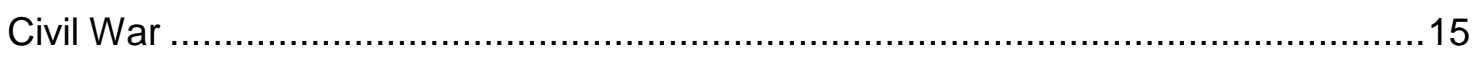

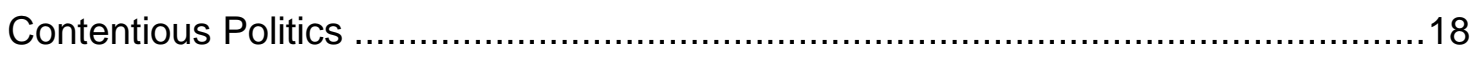

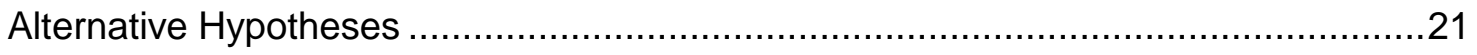

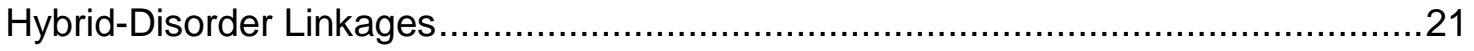

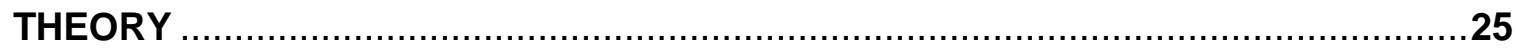

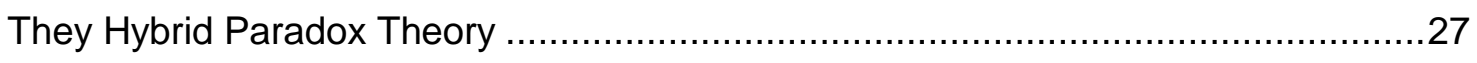

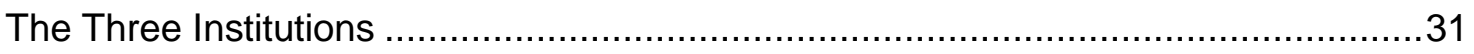

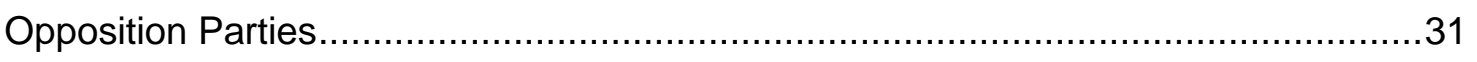

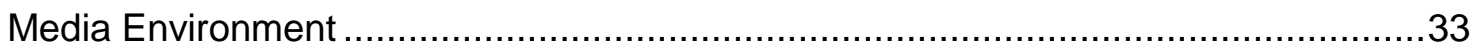

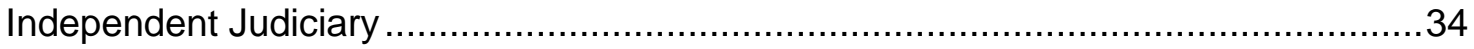




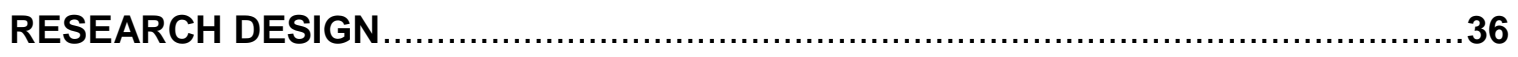

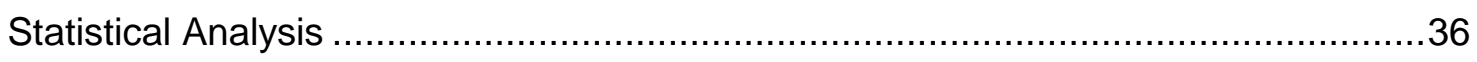

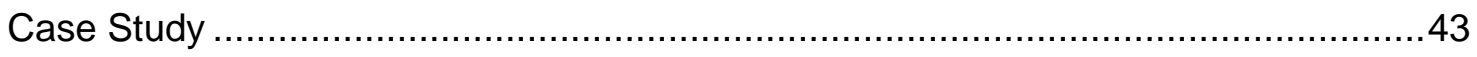

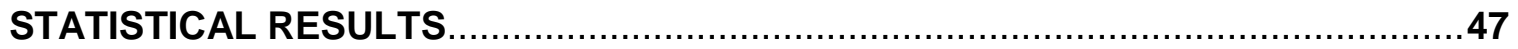

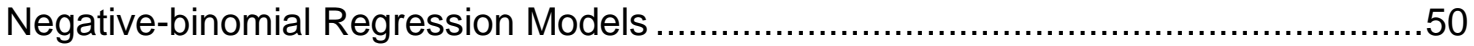

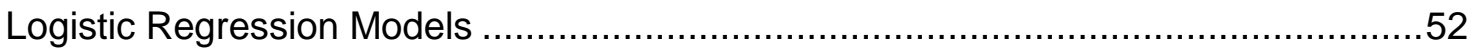

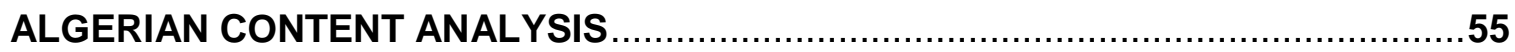

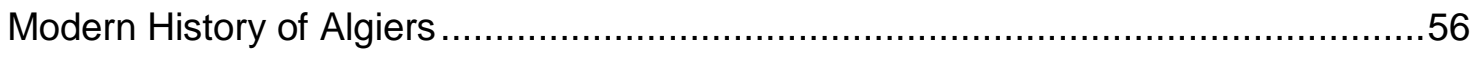

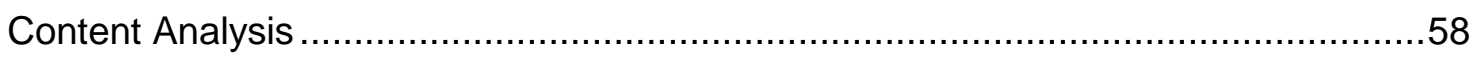

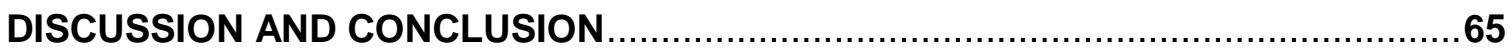

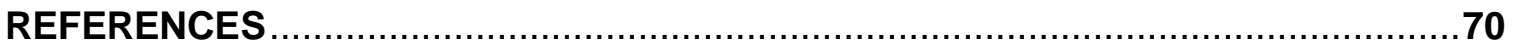

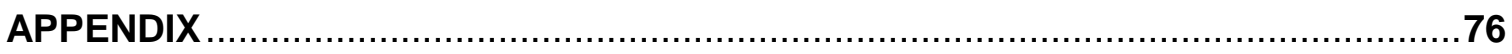

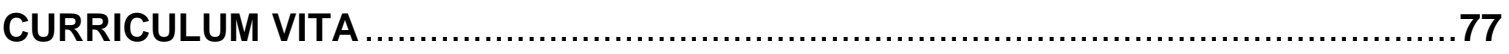




\section{LIST OF TABLES}

$\begin{array}{ll}\text { TABLE } & \text { PAGE }\end{array}$

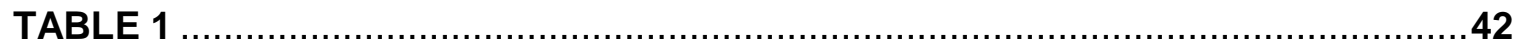

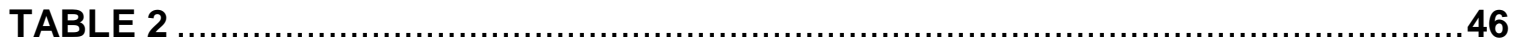

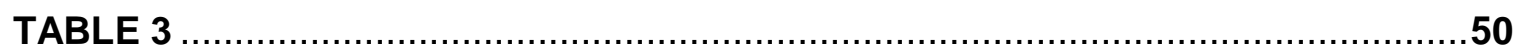

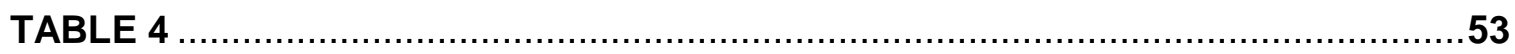




\section{LIST OF FIGURES}

Figure

GRAPH 1

GRAPH 2

GRAPH 3 .

GRAPH 4

GRAPH 5 .

GRAPH 6

GRAPH 7
PAGE .40 .44 .45 .47 .49 .52 .54 


\section{INTRODUCTION}

There is a long tradition in political science of studying governmental structure; this can be tied all the way back to Aristotle's famous work Politics. In modern scholarship, the focus upon the rules, regulations, and institutional makeup of states has been classified as the study of regime type. It is easy to understand why scholars would choose to focus on this topic, both in ancient times and more recently. The nature and characteristics of the polis, and in modern times, of the state have significant repercussions for the humans who inhabit them.

However, in the past two decades this research has certainly taken on a nature different from what any scholar previously would have predicted. The dominant theme of government structure heading into the twenty-first century was the idea that with the collapse of communism all governments would begin the process of democratization and democratic consolidation (Fukuyama 1992).

While Fukuyama was correct about some aspects of the future, he and other scholars at the time did not know, and could not have known, that a new regime type was in the process of solidifying its place in the world. Scholars were quick to take note of a growing number of states that looked neither like full democracies nor like authoritarian regimes. Termed hybrid regimes, they are the most recent example of regimes that fail to fit into traditional regime categories. 
While the field has yet to settle decisively upon a single term to encompass these regimes, this paper will use the term hybrid regimes (see Diamond 2015 for a reference definition for this term).

Hybrid regimes are unique in their construction from the characteristics of both democratic regimes and authoritarian regimes (see Levitsky and Way 2010, for examples). Scholarly concurrence can primarily be found on two fronts as it relates to hybrid regimes: first, that these regimes both exist and are significantly different from the two other major types of regimes to warrant their own classification and study (Diamond 2015); and second, that it is critical to understand how these significant differences with regards to regime type influence both the behavior of the state and the behavior of people within the state is critical.

It is where these new regimes intersect with political disorder, and precisely how they may give rise to political disorder, that concerns this paper. Political disorder is a broad term that encapsulates many types of behaviors, but they all share a common trait: a group of individuals organized on the basis of some political goal or motivation. ${ }^{1}$ According to the Peace Research Institute of Oslo, the organization which produced one of the datasets employed in this paper, includes protests, demonstrations, riots, and armed conflict all as types of political disorder.

\footnotetext{
${ }^{1}$ While the term utilized for this paper will be political disorder, as that is the term utilized by the PIRO dataset, there are other terms which have also been applied to this collection of activities. The term which will most closely fit with the observed activities is Contentious Politics. This term will be defined and addressed further in the literature review section of this paper.
} 
In a similar fashion to the study of regimes, the study of political disorder has seen a recent growth of scholarship and change or expansion in focus. Even before the collapse of the Soviet bloc scholars in the field were aware of the new way in which people were engaging in political disorder (Tilly 1978, for example). This new form of disorder (as opposed to civil wars, which previously held the main focus in the study of political violence) spanned a spectrum of activities ranging from non-violent protest to armed attempts at challenging the state. The study of political violence based around urban population centers rather than the traditional agrarian based insurgencies, as was typically seen in civil wars, has exploded in terms of both scholarship and real-world occurrences. This explosion of urban-based public disorder was on full display throughout the Arab Spring, both in terms of occurrence and in terms of scholarly attention (for example of this literature see Bennett 2012, or Lynch 2014).

Scholars are deeply divided on the grounds of how these new forms of political violence related to more traditional forms. Some have embraced this new urban mass-mobilization political activity as a new façade to an old tradition, and thus have readily applied previous theories as explanations (Tilly and Tarrow, 2015). Others have asserted that they are born out of new causes, and thus we are only seeing their rise to prominence now.

This thesis concerns itself directly with bridging the gap between hybrid regimes and political disorder. Specifically, the task set forth within this paper is to understand how the combination of regime characteristics present in hybrid regimes leads to an increased propensity for political disorder. 
Therefore, this paper is an attempt to contribute to both of these critical topics and to do so it will address a set of critical questions: Are hybrid regimes more likely to display a higher propensity for political disorder events? What characteristics within hybrid regimes result in the increased propensity for political disorder?

The assertion of the overall paper is that hybrid regimes display an increased propensity for political disorder events.

$\mathrm{H}_{1}$ : If regime hybridity increases, then occurrences of political disorder events will also increase.

Furthermore, this paper also concerns itself with uncovering the causal process through which hybrid regime characteristics encourage political disorder. The hypothesized mechanism tested in this paper is that the allowance of opposition parties is responsible for the increase in political disorder.

$\mathrm{H}_{2}$ : The presence of opposition political parties in hybrid regimes is the causal mechanism through which increasing propensity for political disorder arises.

This paper is essential for several reasons. First, it examines the paradox of hybrid regimes, something that has yet to be fully explored. Up to this point, most scholarship has been primarily focused on setting out typologies or categories for these new hybrid regimes to various degrees of success. Attempts at answering crucial research questions, for example, regarding how the hybridity of these regimes affects broader governmental characteristics, is one of the 
primary concerns for the field. Secondly, the identification of factors or variables that affect the propensity of hybrid regimes to experience political disorder could be utilized in thinking about how to provide stability in these regimes. Finally, political scientists have often seen the purposeful weakening of democratic institutions as perplexing, witnessing actors who seem to be weakening their own ability to govern effectively. Hybrid regimes have often taken the act of restricting their own institutions to the extreme. Thus, an examination of how hybrid regimes survive with eroded democratic safeguards while experiencing high levels of dissent may lead to a better understanding of not only hybrid stability, but the logic behind institutional weakening.

This paper is organized as follows: section two explores, the existing literature on the topic of hybrid regimes and political disorder and examines the emerging question of new hybrid regimes may interact with political. Section three explores the theory proposed by this thesis and explains the causal mechanism. In section four the research design, for the statistical analysis and case study portion of the research are explained. In section five the results from the statistical analysis are presented and discussed. In section six the results from the content analysis of newspaper articles from the case study on Algiers, Algeria is revealed, and some historical background on the case is provided. Finally, section seven features the discussion of the summation of the findings of this paper as well as the conclusion to the paper. 


\section{EXISTING LITERATURE}

This section of the paper focuses itself on addressing the existing literature that has built up around both hybrid regimes and political disorder. Through the existing literature, two things become apparent: first the extensive scholarly traditions that exist surrounding both topics, but also the current gap that exists around their intersection that the thesis hopes to contribute to bridging. The outline for this section is first an extensive review of hybrid regime literature, then a review of the existing literature on political disorder, and finally a brief look at the works that have found themselves at the intersection of the two topics.

\section{Hybrid Regime Literature Review}

The first mention of hybrid regimes comes from Terry Lynn Karl (1995) in response to the observed Central American states that displayed both democratic and authoritarian characteristics. Scholars did not gravitate to this term until much later. Instead, in the interim period between the writings of Terry Lynn Karl and the modern resurgence of the term hybrid regimes, a plethora of concepts, terms, and typologies were created, resulting in a chaotic maelstrom of previous scholarship.

This chaos can be organized into three schools of classification. The first school arose relatively shortly after the work by Karl and focused heavily on the 
democratic characteristics of these regimes. Broadly this group of literature has been termed democracy with adjectives (Collier and Levitsky 1997). Mainly in response to this wave of scholarship the second classification was formed. The second classification responded by highlighting the authoritarian features maintained by these regimes, in direct contrast to the first group. Finally, scholars have recently returned to the term hybrid regime, choosing either to focus on both authoritarian and democratic traits equally, or to highlight the fact that regimes exist in a multi-dimensional space, rather than on a single spectrum.

\section{Democracy with Adjectives}

The first significant classification group mostly follows after the end of the Cold War and is primarily influenced by Huntington's theories. By focusing on the procedural definition of democracy, developed from the work of Joseph Schumpeter (1942), scholars undoubtedly noticed numerous regimes that almost meet the definition and thus began the process of adding adjectives to typify these new regimes. However, as scholars became increasingly aware of these regimes and their inability to meet even a procedural minimum definition, they remained focused on the democratic features the regimes did possess. Some scholars have suggested that this focus is a direct result of the work by Huntington (1991) as expectations surrounding democratic consolidation during this time-period were greatly heightened (Collier and Levitsky 1997).

Thus, the literature around this time-period became plagued with vague terms like 'illiberal democracy' or 'transitional democracy,' which were usually applied to a subset of the total population of non-democratic, non-authoritarian 
regimes, leaving the scholarship quite disorganized (Zakaria 1997, and Hamot 1998). Each of these scholars set out a typology for portions of these regimes through the establishment of their own standards and characteristics. The studies conducted during this gold-rush time-period ranged from incorporating vast swaths of these unaccounted-for regimes to sometimes singling out two countries for classification (O’Donnell 1994, Garreton 2003, and Barnes 1998). Despite their weaknesses, these studies did manage to bring increased scholarly attention to the growing number of cases unaccounted for by current terminology.

Ultimately none of the individual typologies have remained in the scholarship, though towards the end of the twentieth century, there were several attempts to consolidate the sum of these adjective democracies to come up with a useful composite. These works were both crucial in both highlighting the number of cases that existed that current regime typology did not capture and highlighting the need for a single term for them. However, neither of these works which attempted to bridge all of the literature surrounding democracy-withadjectives advanced their own singular term as they both focused on bringing about cohesion to the field (Collier and Levitsky 1997, and Collier and Adcock 1999).

The minute yet critical differences between typologies which prohibited a unified field from forming may ultimately be to blame for the fading of scholarship focused on the democratic aspects of regimes. Scholars, potentially unsatisfied with the lack of consensus being brought about purely by focusing on the 
democratic facets of the regimes, turned instead to focus on the authoritarian aspects.

\section{Beyond Democracy}

The second wave of scholarship in the field of hybrid regimes can be typified as a response and opposition to the first wave. It is important to note that at times the scholars in this field may have been focusing on cases in such a manner as not to have seen contestation between themselves and previous scholarship in such terms. The primary focus of this period of scholarship was around viewing these uncategorized regimes through an authoritarian lens. The other significant difference that exists between this period of scholarship and the previous democratic period is the more consolidated research and scholarship that took place. As opposed to a large number of scattered writings and categories, three typologies, and thereby three main avenues of research, came to dominate this period. While other smaller works indeed did exist, attention during this time is and has been focused mostly around the major three works of scholarship. These three major works are Schedler's Electoral Authoritarianism (2002, 2006, and 2015), Ottaway's Semi-authoritarianism (2003 and 2013), and Levitsky and Way's Competitive Authoritarianism (2002 and 2010).

Schedler's work highlights that these regimes are not democracies that have failed to meet the all of the minimum requirements needed to be considered fully democratic, and that they are instead authoritarian regimes that have adopted elections as a means of increasing regime legitimacy (Schedler 2006). By focusing more heavily upon the authoritarian nature of these regimes a more 
pragmatic and practical view of these institutions and their purposes was reached. It is also apparent that these regimes are moving to allow elections as a strategic political choice, rather than being forced to do so. This work undoubtedly laid the foundation of thinking as one of the first major works to appear in direct contestation to previous scholarship. However, the major shortcoming of this work stems from the concentration on the potentially democratizing effect of autocracies implementing elections thus subverting their durability.

Ottaway's conceptualization of semi-authoritarianism follows in much the same respect as Schedler's conceptualization. Ottaway seems potentially more suspicious of these new electoral institutions than previous scholarship, and with a stronger emphasis on the lack of true contestation (Ottaway 2013). Comparatively, Ottaway views these new institutions as democratic trappings, whereas Schedler views them as institutions of uncertainty. This is not to say that Ottaway does not make a case for the ability of these regimes to transition, or even the case that they are not distinct from other autocracies. Indeed, there is room within this work for regimes to remain stable, in a concept known as regime equilibrium. Where this work shows growth from previous scholarship is in the focus on informal coercive mechanisms that must be employed to avoid international attention and maintain some semblance of democracy. This has substantial implications for hybrid regimes and is of particular importance to this work as it focuses on political disorder an event that requires some form of answer from the regime. 
Levitsky and Way's work conceptually is in many ways situated in the middle ground between Ottaway and Schedler. Their work has the added benefit though of being the most stringent in terms of regime characteristic requirements. Focusing both on the presence of certain institutions - like multi-party elections, and a plural media environment - and the violation of one of three primary democratic attributes: free elections, broad civil liberties, and a reasonably level playing field (Levitsky and Way 2010). This work makes two significant contributions to the field. First, is the dual understanding that the competition that occurs in these regimes is real, but entirely unfair. Second is the idea that elections may serve two distinct purposes: the first purpose is increased regime legitimacy by citing successful elections, and the second is the ability for people to predictably build opposition.

The summation of the contributions from these three seminal works is a clear emphasis on regimes that possess the electoral institutions of democracy (at least for the executive) but fail to uphold free and fair elections. Theoretically, this is important as a source of political disorder can be seen in this typology as outlined.

The one feature that all three of these significant works share though is the recognition of a wide swath of regimes that exist between fully authoritarian and fully democratic, and while they all encompass differing amounts of this spectrum, they all acknowledge it. Furthermore, they all utilize the term 'hybrid regime' to define the totality of these regimes. This demonstrates the solidification that has taken place in scholarship regarding the terminology of 
these regimes since the beginning of the twenty-first century. This brings us to the last grouping of scholarship, which focuses not on these regimes as being democratic or authoritarian, but as regime typologies distinctly unique enough to necessitate unique terminology.

\section{The Resurgence of Hybrid regimes}

The return to utilizing the terminology as it was laid out in 1995 seems to be the trajectory of recent scholarship. The defining feature of this scholarship is the multi-dimensionality of regimes. Regime competitiveness has been one of the most critical conceptualizations to come from this most recent scholarship (Diamond 2015, and Gilbert and Mohseni 2011). It has also been marked by attempts to bring together all, or most, of the past attempts at regime typifying in order to bring about order to the field.

In the last decade and a half, scholarship on the topic of hybrid regimes has grown substantially. This has grown from focusing on the categorization of regimes which much of the previously mentioned scholarship dealt with, to understanding how hybrid regimes function differently from their democratic or authoritarian counterparts. Some of these scholars have dealt with trying to come up with precise measurement and analysis strategies for hybrid regimes (Ekman 2009, Wigell 2008, Bogaards 2009, and Morlino 2009). Others still have emphasized the importance of hybrid regimes to democratic consolidation and transition (Brownlee 2009, Howard and Roessler 2006, Donno 2013, and Bunce and Wolchik 2010). Another group of scholars has focused attention on how 
hybridity affects the outcomes of social movements and protests (Roberson 2010, Greene 2014, and Wheatley and Zurcher 2008).

\section{Critiques}

Through the tracing of the evolution of the scholarship on hybrid regimes, it is apparent that previous scholarship has several gaps. First, due to scholarship taking decades to find common ground on a term for these new regimes (in addition to the time it took to recognize their emergence), scholarship focused on the characteristics of these new regimes has been slow in coming about. It is only within the past few years that significant scholarly attention and effort has been placed on attempting to understand these regimes. It is vital to try to understand how the characteristics of these regimes impact their actions and behavior.

Second, there is some evident bias in early scholarship which focused attention too heavily upon only certain kinds of institutions. Scholars in both of the first two waves could rightly be accused of focusing attention too heavily upon only institutions of one kind. The first wave of scholarship was evident in its emphasis placed on democratic institutions. The second wave similarly placed more attention on authoritarian institutions. This oversight by early scholars to take a balanced approach and recognize the equal importance of both types of institutions has resulted in a bias permeating the work done on understanding the characteristics of these regimes. Therefore, it is with a skeptical eye that one must view works from the first two waves of scholarships when considering their assertions about the role of institutions, and characteristics of the regimes. 
Finally, while scholarship has undoubtedly exploded in a plethora of differing directions, adequate attention has not yet been paid to one of the most critical topics in modern-day political science. Political disorder, in its many forms, has yet to be explored thoroughly with respect to regime hybridity. While some attempt has been made, it fails to explore a causal mechanism that is at work (Urdal and Hoelscher 2012). It is these three significant gaps in the hybrid regime literature which this paper hopes to aid in filling.

\section{Political Disorder Literature Review}

The term political disorder as it applies to this thesis encompasses a wide array of topics. Turning to the definition that is utilized by the Peace Research Institute of Oslo's Urban Social Disorder dataset,

The dataset covers different forms of violent and nonviolent politically motivated disorder, including demonstrations, rioting, terrorism, and armed conflict. ${ }^{2}$

This broad swath of activities may seem to make it difficult to know what literature should be explored regarding previous scholarship. In order to deal with this recognized difficulty in selecting which scholarly tradition to focus on, two scholarly traditions are explored in this literature review. First is a review of the literature on civil war. Civil war literature that has arisen over the propensity for countries to experience civil war is selected as one approach because it represents the most extreme of the events covered by the dataset. By focusing on the extremity, the hope is that the other, less extreme events may stem from similar causes, and thus share an explanation and theory. The second approach

\footnotetext{
${ }^{2}$ Urdal and Hoelscher 2012, pp. 516
} 
is to focus on the literature surrounding contentious politics. This term seeks to combine a wide array of social movements citing the common traits that are shared between them.

\section{Civil War}

Scholarship on civil war has grown substantially in the past two decades, as attention in mainstream scholarship turned its attention from interstate war to intrastate conflict. This trend has reflected the trend in the world of conflict being predominately associated with within state conflict rather than between state conflict (see Fearon \& Laitin 2003 for an overview of this trend).

Scholars after becoming aware of this trend turned to understand what was driving this trend and what determined or influenced a country's propensity for experiencing civil conflict. From this scholarship, several important findings remain today.

The first significant group of scholarship to develop around civil wars and their causes argued that civil wars arose when there exists an identifiable group of people that were systematically denied access to power (Gurr 1993, and Collier and Hoeffler 2004). Access to power in this scholarship can mean several things simultaneously. For example, it could mean an ethnic group being denied the right to vote or to have their voice represented. It could stem from the persecution of candidates on religious grounds. These various denials of access have spawned terms such as material deprivation to define the nature of the denial of access to power. Putting aside what access to power means in any 
particular context, though, the explanation forwarded by these scholars was that civil wars resulted from the persistent denial of power and opportunity relative to other ethnoreligious groups. This scholarship has since been coined the "Grievance Explanation" of civil war.

This second major grouping of scholarship arose in direct contestation with the first. The second camp that arose asserted that the motivations for participation were typically not as noble as the Grievance Explanation may imply, but instead arose from the presence of lootable resources. Individuals might claim to be engaged in rebellion for a myriad of reasons but underneath it all they were primarily concerned with economic gain for themselves. Typically, in the Greed Explanation for civil war, there exists a group that is systematically denied access to economic advantages. One of the most common sources of this stems directly from states that are burdened or cursed with mineral wealth (Ross 2004, Humphreys 2005, and Ross 2006). This camp has been coined the Greed Explanation of civil war.

Unfortunately, these findings were at odds with more qualitative scholarship that found deep divisions along religious and ethnic lines that accounted for a countries probability of experiencing civil conflict. Furthermore, this work countered the claims made by both previous scholarships, citing not individual motivations as the reason people would join, but more profound cultural sentiments which made joining the fight necessary. Instead of focusing on the rational reasons that might account for someone to join in the armed rebellion against the state, this scholarship sought underlying cultural motivators, 
things like ideology or religion (Wood 2003). The reason that Wood and other scholars likely picked up on this cultural motivation for participation in civil war is their use of qualitative methods rather than reliance upon statistical analysis.

A fourth primary school of thought that has been established in the civil war sub-field has asserted that the propensity for civil war relies on the opportunity to fight. This school argues that if any of the other reasons were a sufficient condition alone for civil wars to occur, then there would have been far more civil wars than there have been. Therefore, there must be conditions occurring in these countries that allow for civil war to occur (Fearon and Laitin 2003). Though numerous measures are used for this term, it can be boiled down to opportunity. This means that structural conditions exist within a country that increases the likelihood of people to believe that a civil war could succeed. Regarding their measurement these conditions range from having a large population to the presence of inaccessible terrain (Fearon and Laitin 2003). Each of these features though similarly enhances the ability of non-state actors to face the state with some degree of success.

From these works, and the lack of a conclusive answer, scholarship exploded in a multitude of different directions. Some scholarship has highlighted the geographical layout of countries and their population distributions (Buhaug and Gates 2002, and Raleigh and Hegre 2009). Still, others have cited the significant presence of refugees (Salehyan and Gleditsch 2006), declining state capacity (Theis 2010), increasing globalization (Olzak 2011), and even rising temperatures indirectly (Burke et al. 2009). 


\section{Contentious Politics}

Contentious politics is a term that was championed primarily by two scholars throughout the last decade of the twentieth century. Their continued application and refinement of the term has ensured that it remains in the vernacular of political scientists today. There are three components to contentious politics; contention, collective action, and politics (Tilly and Tarrow 2015, p. 7-10). To be more specific, contentious politics occur where these three ideas coalesce. Contention is defined in its most basic form as a claim made by an actor against another actor (Tilly and Tarrow, 2015, p. 7). For example, asking someone who borrowed money from you to give it back, is a claim made on them. This gets more complex as more actors are involved, and as the claims increase in complexity, but at its most basic structure it is a claims-making action. The synchronized struggle on behalf of some shared cause, belief, or program is the definition given for collective action (Tilly and Tarrow 2015, p. 8). Collective action implies both the presence of multiple individuals who have organized themselves in some degree and the shared belief in some program or policy or other interest that they feel is worth exerting effort for. Collective action can take many forms, from an international boycott of a product to the organization of a petition to challenge a local policy. Finally, neither contention nor collective action by themselves is necessarily political; it only becomes political when government agents become involved. The government can be involved in many different ways. It can be the target of the claim of contention, it can become involved in an effort to keep the peace at a collective action event, or it can be a guarantor for a 
successfully contentious movement. However, it is only once a government agent or agency is involved that a movement, that can be described as contentious and relying upon collective action, that a movement can be said to be a part of contentious politics. The main conclusion from this work, though, is that a wide array of forms of political events can, and should be taken into account: "Once we take the analysis to the level of mechanisms and processes, we discover that similar causes and effects operate across the whole range of contentious politics, from viciously violent to pristinely peaceful" (Tilly and Tarrow 2015, p. 188).

Fortunately, the literature in contentious politics and the mechanisms driving the increase in contentious politics has mirrored the civil war literature in forwarding casual process. The only exception to this is that there is no literature within contentious politics that advance the claim that people are driven to engage in contentious politics on the basis of greed. That seemingly makes theoretical sense, as the increased range of activities implies that monetary gain as a motivator diminishes overall since there are cases in which the gains economically would undoubtedly not be enduring.

The idea that ideology, religion, or some other primary cultural motivator exists propelling people to engage in contentious politics is well established within the literature. Some scholars have chosen to highlight the ability of overarching ideologies to successfully unite and mobilize people for contentious politics (Barrie 2017). Other scholars have looked at the role of religion in promoting contentious politics (Johnston and Alimi 2012). Others still have 
continued the legacy of advocating for broad cultural characteristics that are the cause of increasing contentious politics (Lynch 2014).

Grievance based accounts of contention are also well accounted for, seemingly a natural continuation of the work by scholars that focused exclusively on civil wars. For example, the thesis that grievances and their ability to promote political disorder exist not as a linear relationship but as a non-linear one has been adopted by scholars of contentious politics (Shaddmehr 2014). This has been supplemented by works that look more broadly as socio-financial inequality and its ability to promote contentious politics aimed at redistributive policy outcomes (Mew 2013).

There are even works that have taken up the mantle of promoting the spatial aspect of contentious politics. Following along the lines of theories focusing on terrain and opportunity, two lines of inquiry have arisen in contentious politics. On the one hand, there has been scholarship focusing on the specific terrain surrounding contentious politics and its ability to increase participation (Simmons 2005). Others though have asserted that spatial relationships in cities revolve around social networks. Therefore the social structure of a city or country is also a form of terrain (Eder and Ozlem 2016, and Zemni 2017). There have been several other works that examine the role of media (Leung 2015, and Bennett and Segerberg 2012, for example) and weakening governments and government security (Hazbun 2016).

The significant conclusion from the literature on both civil war and contentious politics is that there are similarities running through both regarding 
the causes that they assert are to blame for their events. This lends credit both to the inclusion of the multitude of events that are part of this research project, but also to the need to examine both classes of literature.

\section{Alternative Hypotheses}

From the existing collective literature from these two scholarly traditions, seven alternative hypotheses are apparent. These seven alternative hypotheses can be viewed in Figure 1 of the Appendix. Each of these differing theories represents a possible alternative explanation for increasing countries propensity for political disorder. However, before turning to focus on this paper's theory, it is useful to examine briefly some relevant literature linking political disorder and regime type.

\section{The Hybrid-Disorder Linkage}

Four works that have been most influential in the realm of overlap between hybrid regimes, and political violence. These are the works by Urdal and Hoelscher (2012), Goldsmith (2010), Hegre et al. (2001), and Geddes (2018). All of these works have directly made the link between regime type and political disorder.

The work by Urdal and Hoelscher informs this thesis in some ways. This work served to highlight the strengths of the PRIO dataset on Urban Social Disorder. In order to do this a plethora of random independent variables were attached to the data. Thus, while there is some similarty between the works regarding the measurement strategy of the dependent variable, only brief 
attention is paid to the other variables, and the conclusions to be drawn.

Furthermore, there is scant attention paid to the statistical finding with regards to regime type on disorder. As a result, while statistically sound, this work does not make logical connections to causal mechanisms to be thought of as an adequate exploration. This work cannot, however, be understated in terms of informing this current project. In fact, it is precisely the gap left in both the literature at large and in this work that this thesis hopes to be able to fill.

The article by Goldsmith, on the other hand, is far more skeptical about the relationship observed in his work. The work broadly explores the perplexing continuation of levels of political violence of in African states, despite a notable decrease in purely authoritarian regimes. While statistically able to demonstrate that hybrid, or, as they are described in the article, semi-democratic regimes, are more likely to experience political violence when compared with consolidated autocracies and full democracies, no general mechanism is presented for the results, and thus they are attributed to unobserved factors instead (Goldsmith 2010). This further indicates that ample statistical evidence for the project exists in scholarship, yet no major attempt has been made to link this statistical evidence to a causal mechanism.

The relationship between regime type and the probability of civil war is explored by Hegre et al. (2001). Focusing on democratic transition Hegre et al. show that semidemocracies, as they label them, are far more likely to experience political violence in the form of civil war. They also include a time variable as a significant factor for the project, incorporating time since the last regime change. 
The findings of the article are that semidemocracies are the regimes that are most vulnerable to civil war (Hegre et al. 2001, pg. 39). While the authors highlight this vulnerability as evidence that democratic transition is even more likely due to the relative advantage of democratic stability, it is also true that autocracies in their findings enjoyed a similar level of stability. Thus, while their reported findings are predisposed in favor of democratization, it is fair to say that their findings are in line with the expectations of this paper. Ultimately, the expectations gleaned from this article are self-destructive in the sense that since they are purporting the inevitability of these semidemocracies eventually transitioning to democracies, then some explanation needs to be provided for their continued survival, and continued appearance on the global stage. Since the authors do not account for this in their article, it is left as a gap in the literature, one this paper hopes to address.

The article by Geddes offers the least direct, but perhaps most pertinent exploration of the linkage between hybrid regimes and political disorder. Utilizing Russia as a case study, an examination of regime hybridity and regime survival via institutions is conducted. While there is no direct reference to political violence, it is apparent that for a regime to survive, political violence is one obstacle that must be overcome. The article highlights the usage of the courts as a tool by which the government could leverage continued autocratic practices at the national level, with concessions at the local level (Geddes 2018, pg. 599). This article shares a focus both on regime survival, and on institutions with this paper. The case study portion of this thesis will emphasize the way institutions 
can be leveraged to simultaneously cause hybrid regimes to experience a higher level of political disobedience events, and also to increase regime survival. The main weakness of this article is the reliance on anecdotal evidence from the Russian case without offering either data or strong qualitative evidence.

From here, the paper will turn to explain the theory that accounts for the proposed relationship between political disorder and regime hybridity. 


\section{THEORY}

There are several questions that this thesis will attempt to contribute. These specific questions are: Are hybrid regimes likely to display a higher propensity for political disobedience events? Do hybrid regimes display a propensity for a specific type of political disorder? What characteristics within hybrid regimes results in the increased propensity for political disorder?

By providing some evidence in helping to fill in these gaps, the hope is to provide a better overall understanding of both of these essential and hefty topics. The way in which these questions will be answered will be addressed more fully in section 4. However, this section of the paper will concern itself mainly with the theory for the proposed relationship between regime hybridity, and political disorder.

Before turning to the theory though, it is prudent to first provide a definition for the dependent variable (political disorder) and independent variable (regime hybridity). The dependent variable for the thesis is political disorder. Political disorder is a vague term that encompasses a wide array of actions. The definition employed for political disorder in this work is "different forms of violent and nonviolent politically motivated disorder, including demonstrations, rioting, terrorism, and armed conflict" (Urdal and Hoelscher 2012, pg. 516). While some scholars may wish to delineate these activities to a greater degree, theoretically it 
may be helpful to group them all together. By choosing to leave all these activities grouped and under an umbrella term of political disorder, it preserves the idea that all these activities, though to markedly different degrees, share a common trait, which is essential for the theory of this thesis. This characteristic of all forms of political disorder and the hurdle that all of them must overcome if they are to come to fruition, is collective action.

The independent variable for the thesis is regime hybridity. The definition of a hybrid regime employed by this paper is, in actuality, going to stem from the definition from hybrid regime scholarship that has proliferated most widely. The definition employed in Competitive Authoritarianism has been the most concise and thus the most applicable definition. Furthermore, even though the measurement strategy employed for identifying a competitive authoritarian regime is more stringent than the measurement utilized here, the baseline is the same. The definition of a competitive authoritarian regime is provided below:

Competitive authoritarian regimes are civilian regimes in which formal democratic institutions exist and are widely viewed as the primary means of gaining power, but in which incumbents' abuse of the state places them at a significant advantage vis-à-vis their opponents (Levitsky and Way 2010, p.5).

The further caveat is added that at least one of three significant cornerstones of democracy is violated: free elections, comprehensive protection of civil liberties, and a reasonably fair contest (Levitsky and Way 2010, p. 7). Of most importantance though, and the reason this definition is employed over the 
others that exist is the consideration given to institutions. A media environment that has some degree of independence, a judiciary that is at least semiindependent, and a visible opposition (usually in the form of opposition parties) are all critical components of a hybrid regime.

With both the dependent and independent variables having been suitably explained and defined, attention will now turn to the theory.

\section{The Hybrid Paradox Theory}

The theory of this thesis is a theory of institutional structure, one that asserts that the structural conditions presented by a regime type will play a role in determining the propensity for political disorder. Relating this to the dependent variable, the shared trait between the swath of activities included in the definition of the dependent variable is collective action.

Collective action is oft cited as a problem for many political and nonpolitical activities. In essence, in order for an activity such as a protest to occur, the collective action problem must be overcome. In this scenario, as collective action relates to political disorder, there are two primary components that must be met in order for the collective action problem to be overcome: the need to engage in political disorder, and the will to engage in political disorder.Therefore, any time an individual is considering engaging in political disorder, they must weigh on one hand the need to engage, and on the other hand the will to engage. This theory asserts that both the will and the need to engage in political disorder change drastically as you move across regime types. 
In this instance, need means that the goal of the would-be participants can only be achieved through extra-political means. The possible goals of these would-be participants are wide-ranging, from changes in policy, to access to political power, to ceding of territory or independence. However, the main connector is that all of these goals would be unobtainable by working through the political system. Thus, the would-be participants are forced to work outside of the current political system to attempt to achieve their goal or goals. Going outside of the political system, in this instance, would mean engaging in political disorder. Will in this instance means accepting the consequences of engaging in political disorder. Again, consequences can range greatly. At one end of the spectrum, the consequences in engaging in political disorder are merely the cost of time and energy to join in; at the other extreme is the potential of death.

Democratic regimes are typically designed in such a way that there are a plethora of institutions (both formal and informal) with which people may attempt to enact change, or merely vent political frustrations. Thus, democratic states are given the benefit of having institutions which directly reduce the need for major political disorder in the first place. Therefore, democracies would be expected to experience political disorder only in dire situations.

Democracies do not really have very few institutions to reduce the will of its citizens. Democratic citizens engaging in political disorder (at least the mild forms) face relatively low-cost consequences, for example, a fine, or a small amount of jail time. Summarily, democracies rely on institutions to handle or 
diffuse grievances that the state may be presented with, and thus prevention is the key for democracies confronted with political disobedience events.

Authoritarian states, on the other hand, mostly do not possess the same institutions that are able to prevent the need for political disobedience events. Prevention through institutions is not a way in which Authoritarian states can deal with political disobedience. However, it is not the only means of prevention. Instead, authoritarian regimes are typically far less hesitant in employing coercive force in a more liberal way against their own populace than democratic states. Authoritarian states (assuming the capacity exists) are able to use their militaries to squash political disobedience events that they do not like. For most authoritarian leaders, the use of military force in this manner is likely a calculus between regime survival and potential repercussions. These rulers are able to use the military force because they don't have the same fear of electoral reprisal that democracies do, and their power is derived mainly from fear, or respect, or a mixture of the two. Authoritarians may be incentivized to be heavy-handed in their dealings with political disobedience, as citizens who witness the crackdown and see the results could, in theory, be much less likely to participate in such events again. Thus, authoritarian regimes are able to use force to bring these events to a swift end, and they are also able to gain some manner of prevention of these events occurring due to the reduction in the will of their populace to engage in political disorder.

Hybrid states have, at best, flawed versions of their counter-parts' institutions of dealing with political disorder, and at worst have none of the same 
resources. They lack many of the democratic institutions which negate the need for individuals to participate in political disorder. They also lack the same authoritarian freedom in employing coercive force against their populace. In fact, this theory asserts that rather than just lacking institutions which lessen the occurrences of political disorder, hybrid regimes may be burdened with institutions that invite political disorder.

Of the totality of institutions that make up a hybrid regime, three are identified in this thesis as institutions that may lead to the increased propensity for political disorder displayed by hybrid regimes. These three institutions are the biased media environment, a semi-independent judiciary, and a crippled, but visible opposition movement which is allowed to exist. Each of these institutions may serve to lower the barrier to collective action, as discussed earlier; political disorder is reliant, no matter the form, on some degree of collective action. Each of these institutions then makes it easier for individuals to engage in political disorder because it lowers the cost of choosing to engage. In this paper, this is the causal mechanism, the underlying interactions that are occurring within the regime responsible for the hypothesized relationship. The causal mechanism deals directly with state institutions, capacity, and will. The duality of hybrid regimes is the very thing that ensures that they fail to capitalize on the benefits provided to either authoritarian regimes with their use of coercive force, or democracies and their plasticity. 


\section{The Three Institutions}

Before turning to these causal mechanisms, it is important to note two things. First, this is a structural theory overall, one that expects that the structure of the government, how it is organized, and the rules and regulations employed, will lead to an increase in propensity for political disorder. Thus, it is unlikely that one institution in isolation or rule could hope to have such a dramatic effect on

the state. This means that at a single point in time all three, or any combination of the three causal mechanisms here may be at work. However, and the second point, is that the institution to which this thesis will pay the closest attention throughout the case-study section of the paper is the opposition party. This is the institution that is viewed by this paper as being the most profound in its effect. It also serves to tie back into the measure of the independent variable. Polity essentially is a scale of how competitive a regime is. Thus, by selecting opposition parties as the institution that is expected to have the most considerable magnitude of the effect, the causal mechanism is tied indirectly with the measurement strategy employed.

\section{Opposition Parties}

As identified by Levitsky and Way (2010) a key feature of hybrid regimes is that they hold elections (p. 11). Unlike authoritarian regimes, this allows a chance for the opposition to operate within public visibility. While this opposition may face serious obstacles in terms of their ability to compete in elections, their very existence is primarily the concern of this project. In an authoritarian setting one major obstacle to collective action is an effort made to stamp out visible 
opposition to the government. However, in a democratic setting, opposition parties represent real alternatives to the current regime. Thus, in democracies opposition parties serve to reduce the need, and thus raise the collective action bar, for individuals to engage in political disorder. When in a hybrid regime a visible but disadvantaged opposition exists, people have an easier time deciding to participate; they know that they are not going to be the first person to take to the streets. The party serves as that first group that has already stepped up to challenge the regime. Thus people can at times feel safer in their participation in political disorder against the regimes. An opposition party's importance is emphasized even further when you consider the networks and organizational structure that parties likely employ in elections. This same network then can be employed in mobilizing individuals against the government at critical times. One of the most challenging tasks, especially in a system that would repress public messages, is organizing the many facets of public disorder.

In addition, hybrid regimes have a flaw identified by scholars of democracy common to presidential systems. The elections and their next occurrence are known in advance and thus citizens, especially those who are politically frustrated, or all together disenfranchised, have a visible window where political disorder may be especially useful. Combine this with the uncertainty that accompanies all multiparty elections, and it is easy to see how patterns of the disorder may arise around these periods. 


\section{Media Environment}

Unlike in authoritarian settings, the media is typically allowed some freedom in hybrid regimes. This means that unlike in authoritarian regimes hybrid regimes do not get total control of the flow of information. Authoritarian regimes typically have their own state-run media which doles out to the public only the information that they choose to disseminate. Alternatively, the media environment in democracies may lend itself to oversaturation of information. By giving citizens the information about dozens of protest events and opportunities, they may become overwhelmed. While there may be a state-run media environment in some hybrid regimes, there is indeed not the same level of governmental control and crackdown. A media that is allowed at least some independence then may increase a regime's propensity for political disorder in a number of crucial ways.

First, the media, at crucial times may decide to act independently and disseminate information. This dissemination of information counter to the regime's wishes may alert individuals to the need to engage in disorder. For example, the media may choose to show images of government-sanctioned violence being carried out or symbolic images of individuals resisting the government. Or, on the tamer end of the spectrum, they may merely inform citizens of a law that is being proposed that is unpopular or notify them of the extravagant lifestyles government officials are leading on the citizens dime. Disregarding the exact nature of the information that is being passed along, each of these instances is making widely known a reason or need to engage in 
political disorder. Thus, being able to be cued in on the need to react or act, may lead directly to an overall increase in the number of times.

Second, it is widely understood that the media's slant or position on an issue is able to some degree to inform the opinion of its consumers. ${ }^{3}$ Thus, the presence of a media outlet that takes a negative stance, or at least not entirely positive stance, toward the government may result in an increase of overall dissatisfaction with the government. In an authoritarian regime almost all media outlets are likely to provide to the consumers a story which gives the most favorable view of the government; whether it be a new policy, the leader's performance, or a government project, they are bound to be described positively. However, the control of the media's slant is likely to be far laxer in hybrid regimes. Therefore, there may be more articles presenting a more pragmatic or cynical view of the government which in turn leads to an overall increase in negative perception. This overall increase in negative perception would again make readily known to individuals that there is a reason to protest. The media outlet could even act as a network to enable people of the same disposition towards the government to connect and organize.

\section{Independent Judiciary}

One of the primary considerations for individuals who decide to engage in political disorder against the government is the risk-reward calculation. One institutional aspect that can alter the perception of how risky it will be to engage

\footnotetext{
${ }^{3}$ Though some debate exists as to the direction of the causal arrow, that seems decidedly less important in this specific scenario.
} 
in political disorder is an independent judiciary. In some regimes, the judiciary, insofar as it exists at all, is basically a puppet of the ruler. This means that those individuals who are arrested while participating in political disorder must expect the sentence to be filled with the cruelty of the ruler they have just contended with. In democracies, judiciaries can act as an avenue of policy production (or removal). By being able to sue the government, or government agents, citizens are able to change policy and thus, individuals are offered an alternative to protesting. However, in hybrid regime settings, this is not necessarily the case. While the judiciary is not always entirely independent in these regimes, it is also true that there are cases where they are allowed to act with reasonable autonomy (Levitsky and Way 2010, p. 14). In such cases, the fear of repercussions for acting against the government is lessened. Instead of facing the potential for direct reprisal individuals engaged in political disorder are offered the supposed impartial view offered by a judge. Thus, when making the decision of whether engaging in disorder against the state is worthwhile, an independent judiciary has the capacity to alter the risk perception enough that more people are willing to engage. 


\section{RESEARCH DESIGN}

This study employs a mixed-method approach utilizing both statistical analyses, and a case study. This strategy is utilized with the aim of having both methods working hand-in-hand both to enhance reliability and better explore the hypothesized relationship. This strategy follows in line with the selection of an "on-the-line" case forwarded by the scholar Lieberman when discussing mixed method research designs (Lieberman 2005, pg. 444). It is also helpful both in establishing the overall hypothesis with regards to regime hybridity, and in allowing for the causal mechanism to be observed. From here, the discussion will first focus upon the statistical analysis before turning to the case study.

\section{Statistical Analysis}

First, the Peace Research Institute of Oslo's (PRIO from henceforth) Urban Social Disorder dataset ${ }^{4}$ is employed in measuring the dependent variable of political disobedience events. The PRIO dataset on Urban and Social disorder measures events, as has been mentioned above for the largest (by population) cities in the Southern hemisphere of the globe. This data set is structured such that political disobedience events are measured at the city level rather than the country level. While there may be some reasonable concern about only

\footnotetext{
${ }^{4}$ Urdal, Henrik \& Kristian Hoelscher 2012. 'Explaining urban social disorder and violence: An empirical study of event data from Asian and Sub-Saharan African cities’, International Interactions 38(4): 512-528.
} 
measuring single city level political disobedience events, the data set is perfect for a cross-national comparative study, as there is a level of control added by only examining cities as opposed to entire countries. Before focusing on the benefits of this type of measure it is necessary to point out that it is unknown what the statistical ramifications are of having a nested model with all variables aside from the dependent variable measured at only one level. Specifically, there is less concern which needs to be paid to 'inhospitable terrain' which is proven to make conducting certain forms of anti-governmental actions more feasible. It is important to note, however, that there are several instances within the data set in which a single country may have two or three cities represented. In order to statistically account for this controls are added to the dataset for any countries that have more than one city represented. Furthermore, the dependent variable is measured yearly, thus, resulting in a dataset that has observations at the cityyear level. There are 2,375 observations in the dataset.

Several notable alterations have been made to the original dataset. First, in the original form of the data, the date ranges from 1960 to 2014 ; this has been narrowed for this project to range only from 1990 to 2014 . There are several reasons supporting this artificial reduction in the number of observations. First, all observations will occur in a post-cold war time frame; this is especially important for the post-Soviet states in Central Asia and the Caucuses region. Additionally, this reduction also allows for superior data availability; in a pre-soviet period, there is less continuity of the data which represent the independent variable, alternative hypothesis, and controls. 
The second alteration of the data set applies specifically to the post-Soviet states in the data set. In order to allow the measures of these states to gain accuracy, the observations for these states only cover the time frame from 19922014. By removing the 1990 and 1991 observations, one hopes that the measures have had time to reach an accurate level of measurement, as the countries gained independence so recently. This is reasonably supported by data availability, as measures for these countries mainly, though not exclusively, become available only in 1992 .

Finally, the dependent variable within the data set, political disobedience events, is measured in a generic count form in the original dataset which includes all types of events. This variable is called NEVENTS. NEVENTS has a range of 0 to 29 and a mean of 1.576 .

Additionally, it has a measure for events in which deaths have been recorded and those in which no deaths have been recorded. Adding to these measures a binary variable has been added, in which a country receives a 1 if during that year there was at least one event recorded, and a 0 if no events were recorded. Approximately 51 percent of the observations in the dataset were years in which an event occurred. This binary measure is utilized for additional statistical reliability.

One of the most widely utilized and accepted measures of regime type is a country's Polity score; this is the measure which conceptual meets the 
requirements for measuring the independent variable. ${ }^{5}$ Polity is a twenty-one point scale which ranges from negative ten, for a regime that is fully authoritarian, to positive ten, for a regime that is fully democratic. It is the middle portion of this range, from negative five to positive five, where hybrid regimes are typically classified. It is prudent to point out that some contestation exists over this measure, with different scholars recommending their own delineations of Polity. This contestation is largely circumvented in this study by instead employing a measure of Polity which has had several transformations done to it. First, the measure of Polity was squared, thus folding the measure and placing at one end of the spectrum all regimes that are fully democratic or authoritarian, and then at the other end all hybrid regimes, thus turning the measure into a measure of hybridity. Then, the measure was scaled from 0 to 1 with 1 representing a fully hybrid regime, and a 0 either fully democratic or fully authoritarian regime. The measure of Hybridity has a mean of 0.575 , indicating that the units in the study are on average slightly more hybrid than not. The outlay of the hybridity measure is displayed below in Graph 1.

\footnotetext{
${ }^{5}$ POLITY IV PROJECT: Political Regime Characteristics and Transitions, 1800-2013 (2014) by Monty G. Marshall, Ted R. Gurr, Keith Jaggers
} 


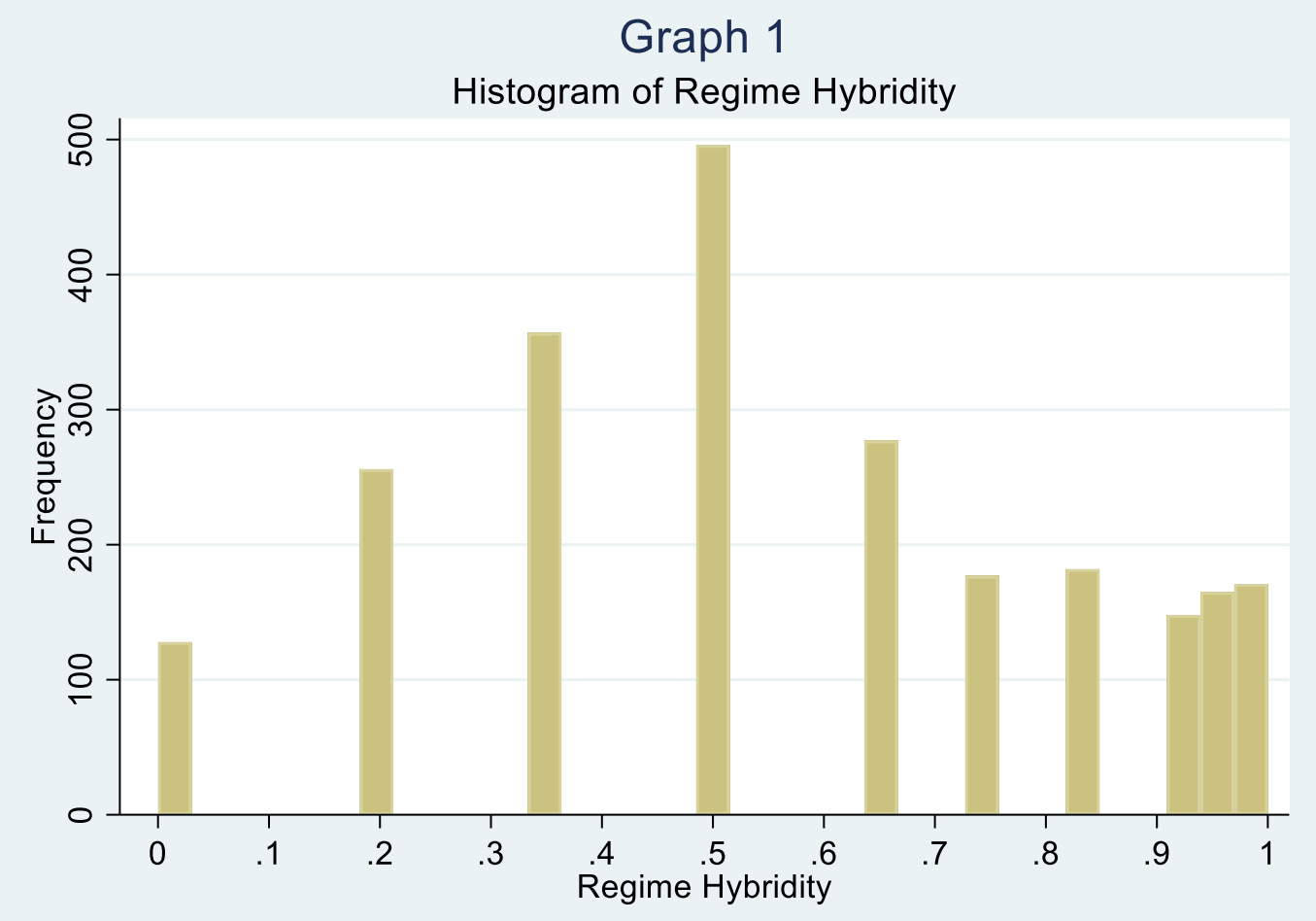

Furthermore, as an additional measure of reliability and validity, a second measure is employed. By utilizing the Varieties of Democracy project measure of polyarchy, which has received a transformation identical to that of the Polity score, the hope is that the statistical findings can be viewed will more trust and be seen as valid. This is important as relying upon a single measure for the independent variable without and validation of its ability to measure what it is intended to measure, runs the risk of the results being spurious. The measure of Hybridity from the V-Dem project has a mean of 0.542 , which is slightly less hybrid than the measure from Polity, but overall still indicates that the sample has more hybrid cases than not.

Three variables within the data set represent control variables for the purpose of this project. The first of these control variables is a simple binary 
variable which measures whether or not the city is the de facto capital of the country. A country's capital may hold symbolic political importance, and therefore may experience a higher level of political disorder events, or as the seat of government, power may be subject to far more control and governmental supervision and thus experience lower levels of political disorder events. In either case, the inclusion of this variable as a control allows the statistical test to function without bias being introduced from capital cities.

The second control variable employed is a binary variable for the years 1990-1995. This variable is included to control for effects that may have resulted from the end of the Cold War and the collapse of the Soviet-bloc. During this turbulent time, countries may have experienced higher levels of disorder than would otherwise be normal. This variable is also binary, with years falling between 1990 and 1995 receiving a 1 and all other years receiving a 0 .

Finally, the level of internet penetration is added as a control variable to help deal with the differing levels of the media environment. Countries that during the time period, consistently had higher levels of internet penetration may have had an easier time in documenting the political disobedience events that occur within the country. In short, by being able to post to the internet that an event occurred these countries may have higher levels of political disobedience events due to better reporting.

Furthermore, eight variables are included in hopes of accurately representing the alternative hypothesis. These eight variables are included below in Table 1. 


\section{Table 1}

\begin{tabular}{|c|c|c|}
\hline Variable & Description & $\begin{array}{l}\text { Alt- } \\
\text { Hypothesis }\end{array}$ \\
\hline Urbanicity & $\begin{array}{c}\text { Percent of Population which resides in an } \\
\text { urban setting. }\end{array}$ & $\mathrm{H}_{9}$ \\
\hline $\mathrm{HDI}$ & $\begin{array}{l}\text { A measure of how well a country is able to } \\
\text { provide essential services to its population. }\end{array}$ & ${ }^{*} \mathrm{H}_{3}$ \\
\hline $\begin{array}{l}\text { Economic } \\
\text { Change }\end{array}$ & $\begin{array}{l}\text { The change in a Countries GDP from the } \\
\text { previous year, lagged by a year. }\end{array}$ & $\mathrm{H}_{9}$ \\
\hline Trade & $\begin{array}{l}\text { A Countries Trade income as a percentage of } \\
\text { its GDP }\end{array}$ & $\mathrm{H}_{6}$ \\
\hline KOF & A measure of Globalization of a country & $\mathrm{H}_{7}$ \\
\hline GDP (PPP) & $\begin{array}{l}\text { The average income for a citizen of a country } \\
\text { in US Dollars, considering Purchasing Power } \\
\text { Parity }\end{array}$ & ${ }^{*} \mathrm{H}_{3}$ \\
\hline GINI ${ }^{6}$ & $\begin{array}{l}\text { Level of Economic Inequality present within a } \\
\text { country }\end{array}$ & $\mathrm{H}_{4}$ \\
\hline MINERAL & $\begin{array}{c}\text { The amount of revenue produced by a country } \\
\text { through the sale of valuable minerals (i.e., } \\
\text { diamonds) }\end{array}$ & $\mathrm{H}_{5}$ \\
\hline
\end{tabular}

It is acknowledged that neither of these measures adequately captures the nuance of alternative hypothesis 3 . However, no adequate measure of ethnic and religious divisions could be found for the countries within the dataset.

Of note in the above table is the absence of alternative hypothesis 8 ; this is because, as mentioned in the literature review, this hypothesis has up to this point only be tested and studied using qualitative methods. This study makes no attempts to bring statistical analysis to bear on a hypothesis which is best studied utilizing qualitative methods, though special attention will be paid to this hypothesis during the case study section of the paper.

\footnotetext{
${ }^{6}$ The GINI coefficient is included within the dataset; even though it cannot be used as a control, due to the very limited number of cases in which there is no measure for GINI is very high, dropping the $\mathrm{n}$ from 2,150 to 705 . More important than the sheer number of cases dropped is also the consideration of which cases are dropped. In other words, it is likely that the cases dropped all share some common variable about them. Thus, the results from including the GINI coefficient are not displayed in the tables above.
} 


\section{Case Study}

The purpose of this case study is again, to provide some measure of reliability for the previous statistical analysis, but more importantly, it is also to provide illumination of the proposed causal mechanism. In this instance, clear evidence and illumination are needed of opposition parties functioning as the mechanism by which Algeria is experiencing a more significant number of political disorder events. Thus, if this is the case three things should be apparent in the content analysis of newspaper articles from Nexus Uni. First opposition parties should be directly named concerning the political disorder events.

Second, the opposition parties in Algeria should be cited as the perpetrator of the disorder, not the recipient (as it could be the case that the events occurring are ones in which the government is the instigator). Finally, mention should be given for the goals of the opposition party concerning the political disorder events. Specifically, there should be some politically motivated goal which the political disorder is aimed at achieving, and this goal should be readily apparent.

The case study on Algiers is conducted by utilizing NexisUni to search all Newspaper articles and broadcast transcripts from 1997, which specifically mentioned Algiers and at least one of a handful of search terms relating to political disorder. ${ }^{7}$

It is necessary to expand on how and why Algiers, Algeria, was chosen as the case to study. In selecting a case, it was first necessary to find cases that

\footnotetext{
${ }^{7}$ The search terms utilized were; violence, protest, riots, demonstrations, and disorder.
} 
both were consistently hybrid and experienced high levels of political disorder. This strategy is known as selecting a case that is "on-the-line" and is useful for selecting a case that illustrates the theory (Lieberman 2005, pg. 444) While several cities in the dataset meet the basic requirements outlined above, Algiers, Algeria is the final selection.

Below graph 2 displays the transformed Polity score or the score of regime hybridity for Algeria throughout the timeframe of the data, 1990-2014. With the exception of a few years in the early 1990s, Algeria has remained unquestionably hybrid throughout the time frame of the study.

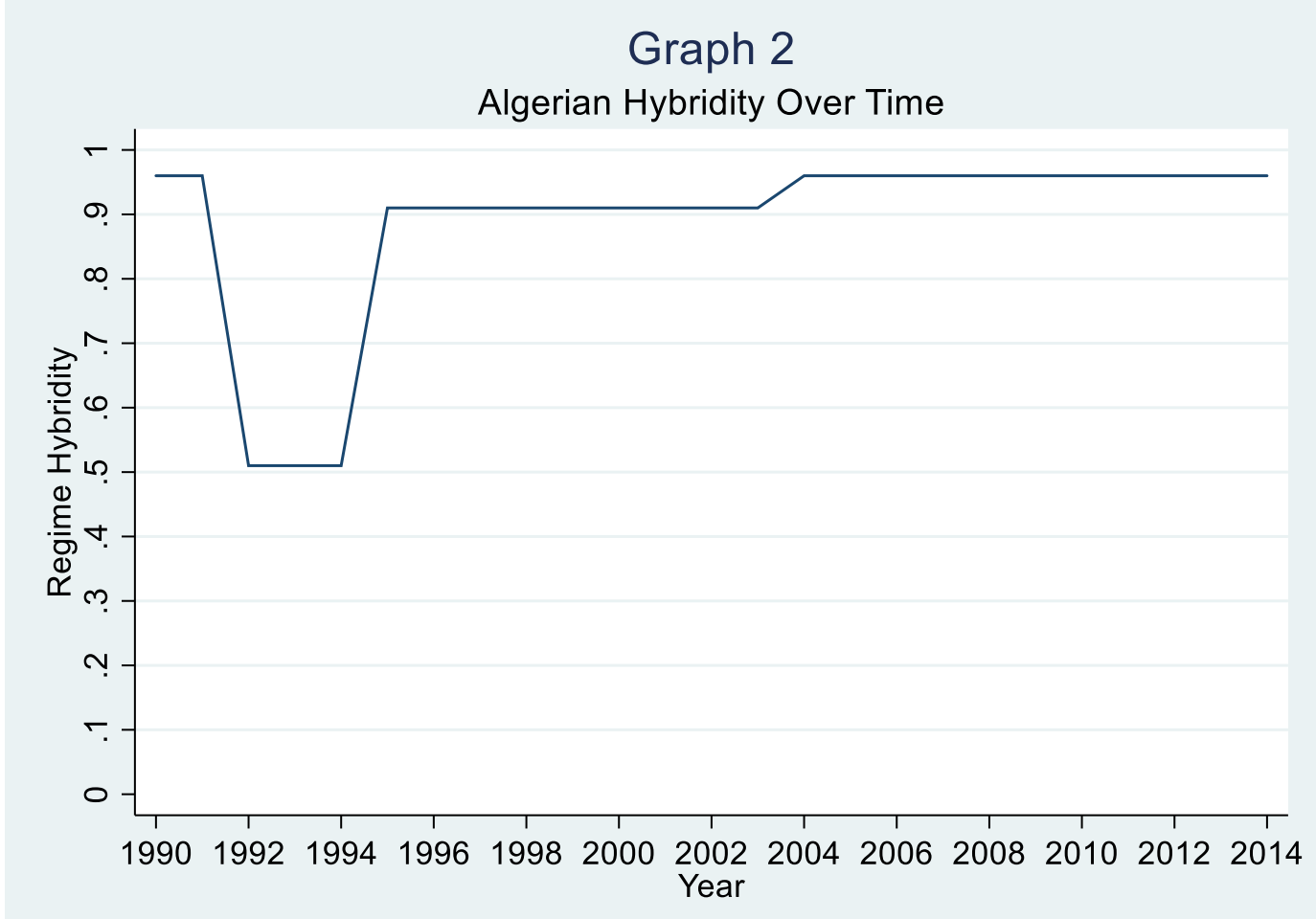

Graph 3 below displays the yearly number of political disorder events that the city of Algiers experienced during the period of the data. Algiers on average experienced 5.360 yearly political disorder events, while the rest of the data has 
a yearly average of 1.576 . Algeria consistently ranges above this average.

Furthermore, graph 3 helped select the year that would be focused on in the case study. ${ }^{8}$ The year 1997 is the year which the case study will focus upon.

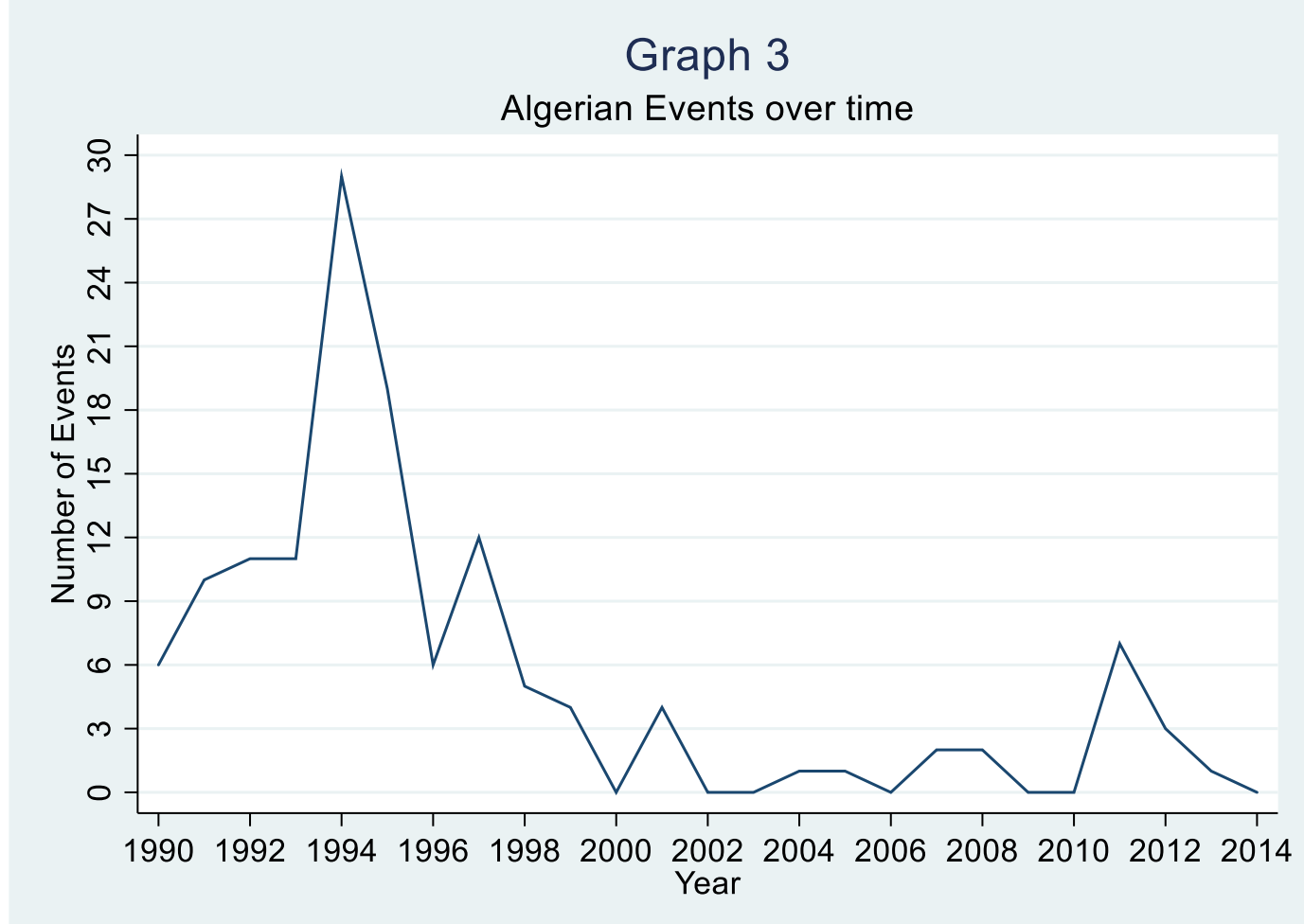

Finally, when comparing Algiers to the average of the dataset, it becomes apparent that Algiers is well situated. As can be seen in Table 2 below, Algiers is well situated within the dataset in that excepting the independent variable, and the dependent variable, Algiers is very close to all of the average values for the data set. It is clear when examining the dependent variable that Algiers has experienced a higher than average number of political disorder events. This observation is valid both when looking at the average number of events 5.360 vs.

\footnotetext{
${ }^{8}$ Due to the space limitations of the paper, it was not feasible to focus upon the full range of years. Therefore, it was prudent to find a year that was most likely to provide insight for the causal mechanism.
} 
1.576 and at the percentage of years in which an event occurred, 0.720 compared to 0.510 of the average for the dataset. Additionally, Algeria is considered to be more hybrid than the average regime in the dataset, and this is also true when looking at either the Polity score variable or the V-Dem score variable. Thus, Algiers is a well-poised case study for this project.

TABLE 2

\begin{tabular}{|c|c|c|}
\hline & Algiers, Algeria & Average \\
\hline Number of Events & 5.360 & 1.576 \\
\hline Events Occurring & 0.720 & 0.510 \\
\hline Regime Hybridity & 0.88 & 0.575 \\
\hline V-Dem Hybridity & 0.656 & 0.542 \\
\hline $\mathrm{HDI}$ & 0.638 & 0.530 \\
\hline Lag Change in GDP & 0.386 & 0.395 \\
\hline Urbanicity & 0.592 & 0.458 \\
\hline Trade & 0.136 & 0.156 \\
\hline Internet & 0.061 & 0.106 \\
\hline KOF & 0.415 & 0.433 \\
\hline GDP(PPP) & 0.050 & 0.062 \\
\hline Mineral & 0.196 & 0.118 \\
\hline
\end{tabular}




\section{STATISTICAL RESULTS}

One of the best ways to examine a proposed relationship is to view the dependent and independent variables together graphically. This is what Graph 4 does; it is a scatterplot of the number of political disorder events observed on the $\mathrm{Y}$-axis, and the regime hybridity on the $\mathrm{X}$-axis.

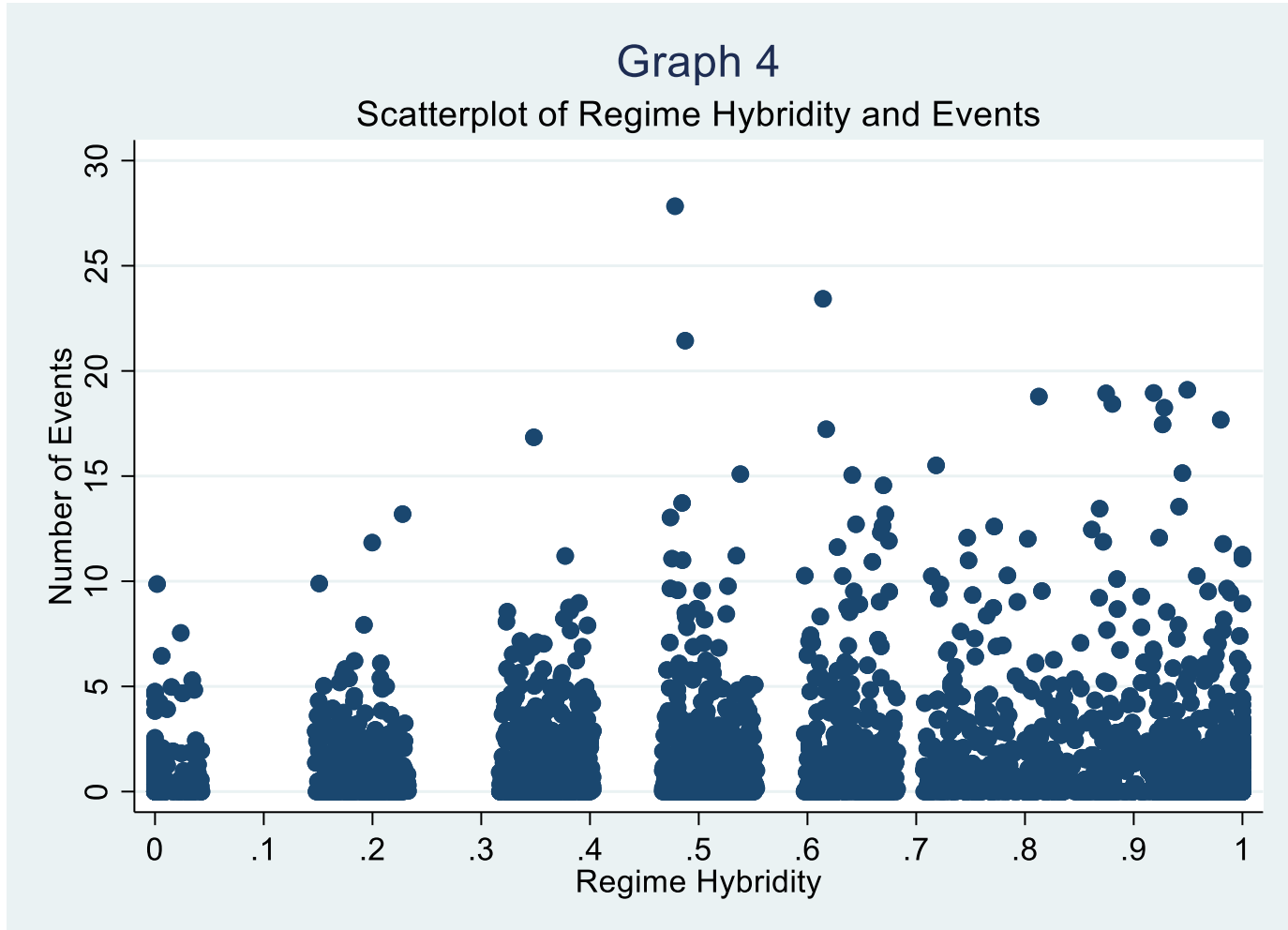

This graph shows a decent relationship between hybridity and number of events, as it is discernible that moving from 0 to 1 on the $\mathrm{X}$-axis, the number of average events increases. Employing a simple linear regression between only the dependent and independent variables, displays a coefficient of 0.823 for regime hybridity, with a standard error of 0.197 (the $p$-value is 0.000$).{ }^{9}$ This is a

\footnotetext{
${ }^{9}$ When using the V-dem measure the coefficient rises to 1.115 with a standard error of 0.217 and a $p$ value of 0.000
} 
small increase of about one additional event in a year if a regime is fully hybrid, as compared to being fully democratic or autocratic. However, as discussed above, the dependent measure, number of events, is a count variable; thus, utilizing standard linear regression is not necessarily the most effective strategy.

For correctly measuring the hypothesized relationship with this dependent and independent variable it is necessary to employ a more advanced statistical regression technique. In this instance, the decision must be between using Poisson, or Negative-Binomial regression. In this instance, it is more appropriate to use the Negative-Binomial model, as the data does not fit a Poisson distribution. This is highlighted in Graph 5 which shows an overdispersion of 2.039, when the standard is a 0 if the Poisson model would fit as well, or better than the Negative-Binomial model. This is also affirmed when comparing the mean of the variable NEVENTS with the variance, the mean is 1.576 , while the variance is 7.365 , the variance is approximately five times larger than the mean. 


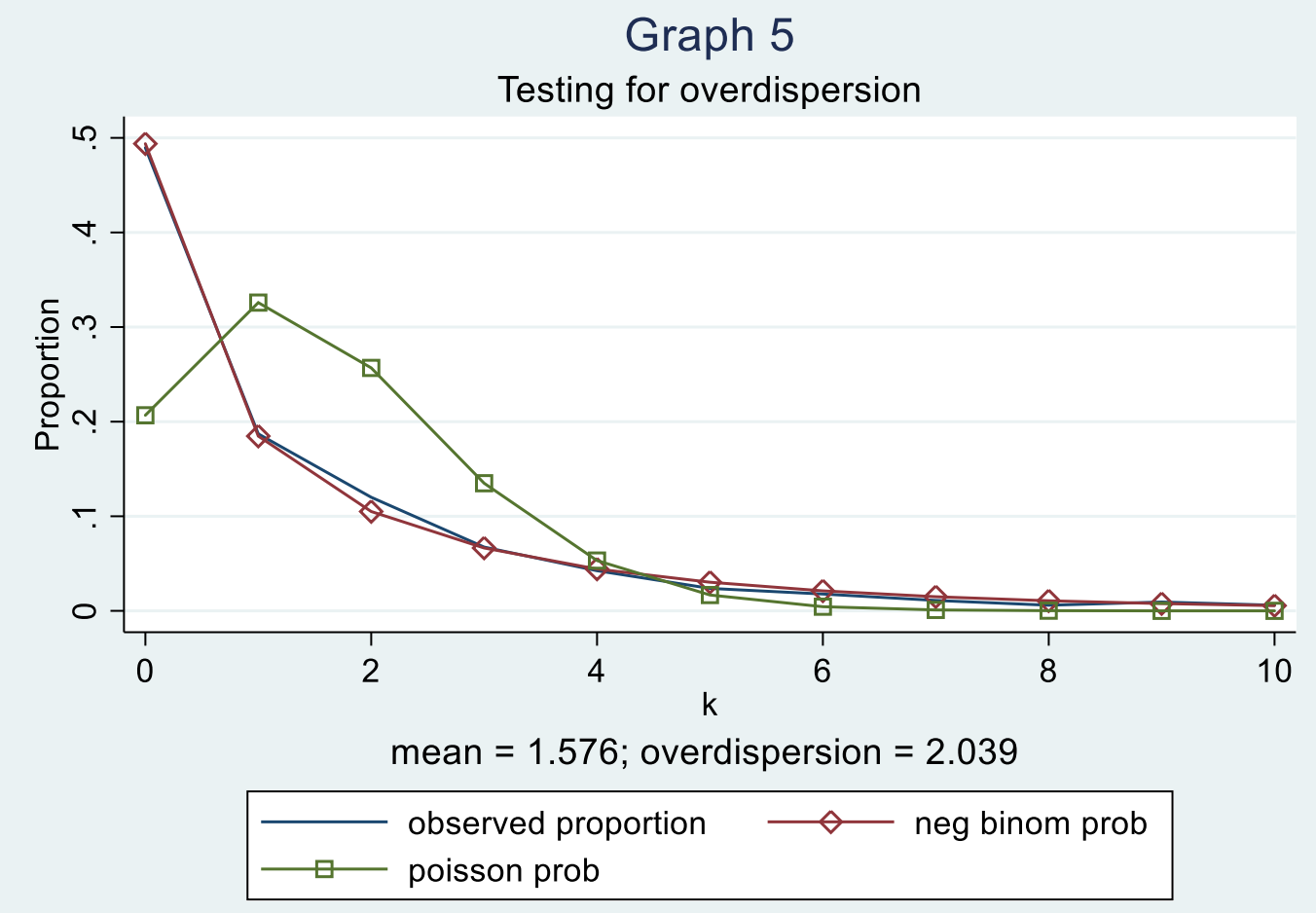




\section{Negative-binomial Regression Model}

TABLE 3

\begin{tabular}{|c|c|c|c|c|c|c|c|c|}
\hline & \multicolumn{2}{|c|}{ Model 1} & \multicolumn{2}{|c|}{ Model 2} & \multicolumn{2}{|c|}{ Model 3} & \multicolumn{2}{|c|}{ Model 4} \\
\hline & $\begin{array}{l}\text { Inciden } \\
\text { t Ratio }\end{array}$ & Coeff. & $\begin{array}{l}\text { Inciden } \\
\text { t Ratio }\end{array}$ & Coeff. & $\begin{array}{l}\text { Inciden } \\
\text { t Ratio }\end{array}$ & Coeff. & $\begin{array}{l}\text { Inciden } \\
\text { t Ratio }\end{array}$ & Coeff. \\
\hline $\begin{array}{l}\text { Hybridi } \\
\text { ty }\end{array}$ & $\begin{array}{c}1.765^{\dagger} \\
(0.217)\end{array}$ & $\begin{array}{c}0.568^{\dagger} \\
(0.123)\end{array}$ & $\begin{array}{l}3.076^{\dagger} \\
(0.453)\end{array}$ & $\begin{array}{l}1.124^{\dagger} \\
(0.147)\end{array}$ & & & & \\
\hline $\begin{array}{l}\text { Hybrid } \\
\text { Polyarc } \\
\text { hy }\end{array}$ & & & & & $\begin{array}{l}2.212^{\dagger} \\
(0.307)\end{array}$ & $\begin{array}{c}0.794^{\dagger} \\
(0.139)\end{array}$ & $\begin{array}{c}1.252^{\dagger} \\
(0.391)\end{array}$ & $\begin{array}{c}0.921^{\dagger} \\
(0.156)\end{array}$ \\
\hline $\mathrm{HDI}$ & & & $\begin{array}{c}45.116 \\
\dagger \\
(17.25)\end{array}$ & $\begin{array}{l}3.809^{\dagger} \\
(0.382)\end{array}$ & & & $\begin{array}{c}10.493 \\
t \\
(3.905)\end{array}$ & $\begin{array}{l}2.351^{\dagger} \\
(0.372)\end{array}$ \\
\hline $\begin{array}{l}\text { Chang } \\
\text { e GDP }\end{array}$ & & & $\begin{array}{l}0.002^{\dagger} \\
(0.002)\end{array}$ & $\begin{array}{l}-6.289^{\dagger} \\
(1.245)\end{array}$ & & & $\begin{array}{c}0.000^{\dagger} \\
(0.001)\end{array}$ & $\begin{array}{l}-7.602^{\dagger} \\
(1.285)\end{array}$ \\
\hline Urban & & & $\begin{array}{l}0.139^{\dagger} \\
(0.040)\end{array}$ & $\begin{array}{l}-1.975^{\dagger} \\
(0.290)\end{array}$ & & & $\begin{array}{c}0.220^{\dagger} \\
(0.061)\end{array}$ & $\begin{array}{l}-1.515^{\dagger} \\
(0.278)\end{array}$ \\
\hline Trade & & & $\begin{array}{c}0.023^{\dagger} \\
(0.011)\end{array}$ & $\begin{array}{l}-3.759^{\dagger} \\
(0.486)\end{array}$ & & & $\begin{array}{c}0.019^{\dagger} \\
(0.008)\end{array}$ & $\begin{array}{l}-3.983^{\dagger} \\
(0.452) \\
\end{array}$ \\
\hline $\begin{array}{l}\text { Interne } \\
\mathrm{t}\end{array}$ & & & $\begin{array}{c}1.518 \\
(0.398) \\
\end{array}$ & $\begin{array}{c}0.417 \\
(0.262) \\
\end{array}$ & & & $\begin{array}{c}1.410 \\
(0.386)\end{array}$ & $\begin{array}{c}0.343 \\
(0.274) \\
\end{array}$ \\
\hline KOF & & & $\begin{array}{r}1.673 \\
(0.657) \\
\end{array}$ & $\begin{array}{c}0.514 \\
(0.393) \\
\end{array}$ & & & $\begin{array}{l}2.655^{*} \\
(0.973)\end{array}$ & $\begin{array}{c}0.976^{*} \\
(0.366)\end{array}$ \\
\hline GDP & & & $\begin{array}{l}0.193^{\dagger} \\
(0.093)\end{array}$ & $\begin{array}{l}-1.645^{\dagger} \\
(0.484)\end{array}$ & & & $\begin{array}{c}0.260^{*} \\
(0.136)\end{array}$ & $\begin{array}{l}-1.348^{*} \\
(0.523)\end{array}$ \\
\hline Mineral & & & $\begin{array}{c}1.864^{\ddagger} \\
(0.538)\end{array}$ & $\begin{array}{c}0.623^{\ddagger} \\
(0.289)\end{array}$ & & & $\begin{array}{c}1.879^{*} \\
(0.572)\end{array}$ & $\begin{array}{c}0.631^{\star} \\
(0.304)\end{array}$ \\
\hline $\mathrm{N}$ & & 2,357 & & 2,150 & & 2,357 & & 150 \\
\hline
\end{tabular}

Where $P>|z|$ is $\leq 0.001^{\dagger}, \leq 0.005^{\ddagger} \leq 0.05$

Other unmentioned variables included in the regression model include a control for the post-cold war period, a control for whether the city served as a capital for the country, and controls for countries which included more than one city within the dataset.

Table 3 reveals two noteworthy observations. First, regime hybridity significantly increases the chances of a country experiencing a political disorder event, even when holding all other variables at their means. Secondly, though, it is surprising that the Human Development Index indicator also indicates that an increase in HDI also warrants an increased likelihood of experiencing political 
disorder events. Thus, before focusing on the findings related to the independent variable, a few words shall be said regarding HDI. There are several reasons which make it reasonable to see this relationship which at first may be perplexing. First, HDI may correspond with a better ability to report or detect the events occurring. In countries where HDI is higher, there is an accompanying increase in literacy and infrastructure which makes recording instances of political disorder much easier than in countries with low HDI scores. Additionally, an increased HDI may correspond with the specifically non-violent activities.

The differences between Model 2 and Model 4 is only the change of the measure of the independent variable. In Model 2 the transformed Polity score is utilized, while Model 4 makes use of the V-dem indicator. In both cases, there is a statistically significant increase in the number of events a unit will experience as hybridity increases. The graphical display of this can be seen in Graph 6. This indicates that a country that is fully democratic or autocratic, which transitions towards hybridity, will on average experience one and a half more political disorder events in a year. 


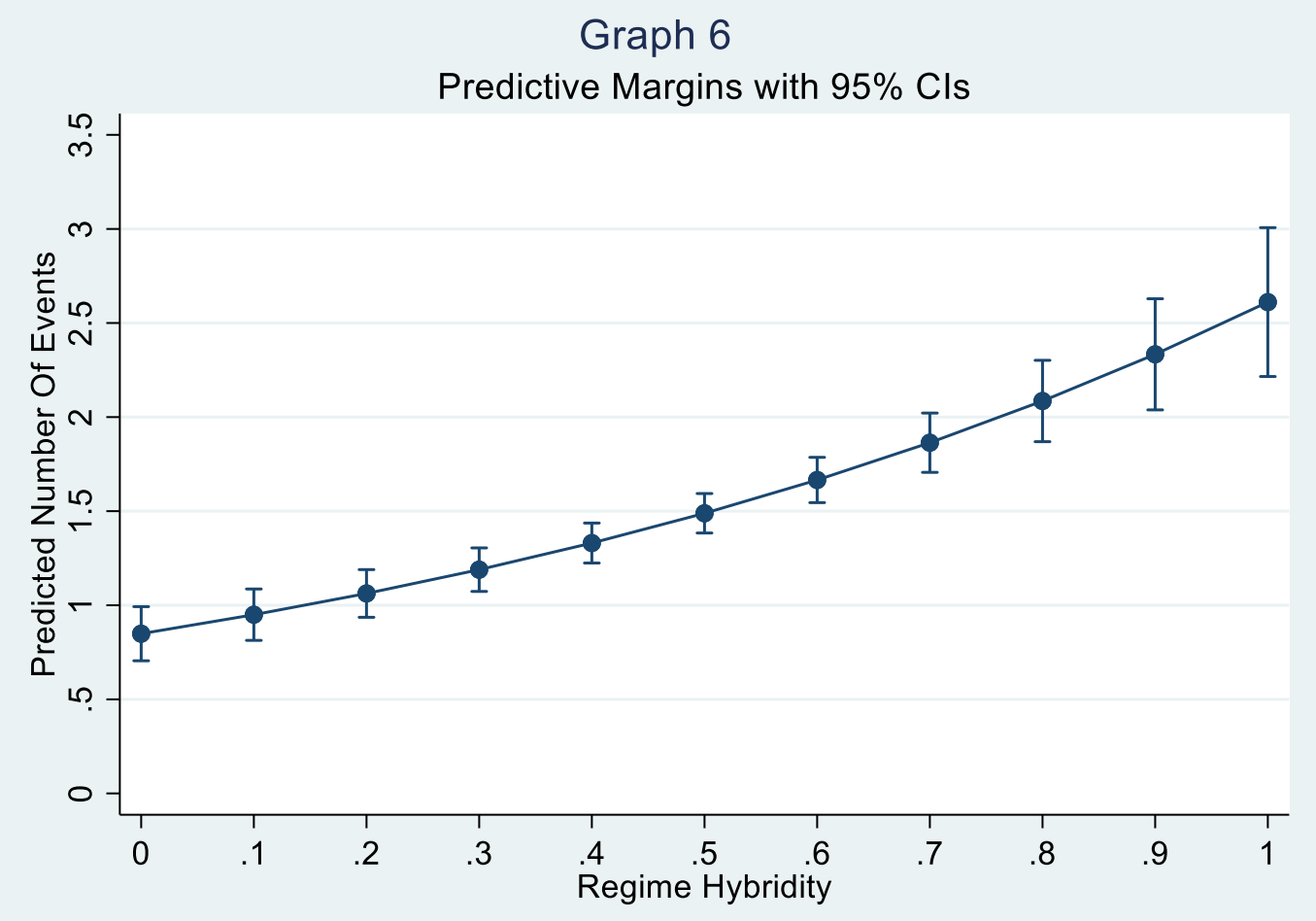

While this statistical evidence is strong by itself, it is also necessary to examine the other form of the dependent variable, that is, the binary form of the variable. By focusing on whether an event occurs within a year, rather than on the sheer number, it is hoped that additional validity will be added to the results. Specifically, the hope is that any potential of numerous events occurring on years of turmoil or transition can be tempered. Thus, if this statistical analysis proves to be like that of the previous analysis, then some criticism can hope to be avoided.

\section{Logistic Regression Models}

Table 4 below displays the logistic regression models 1 through 4 . Model's 1 and 2 again uses the Polity score, while model 3 and 4 uses the V-dem score. 
TABLE 4

\begin{tabular}{|c|c|c|c|c|c|c|c|c|}
\hline & \multicolumn{2}{|c|}{ Model 1} & \multicolumn{2}{|c|}{ Model 2} & \multicolumn{2}{|c|}{ Model 3} & \multicolumn{2}{|c|}{ Model 4} \\
\hline & $\begin{array}{l}\text { Odds } \\
\text { Ratio }\end{array}$ & Coeff. & $\begin{array}{l}\text { Odds } \\
\text { Ratio }\end{array}$ & Coeff. & $\begin{array}{l}\text { Odds } \\
\text { Ratio }\end{array}$ & Coeff. & $\begin{array}{l}\text { Odds } \\
\text { Ratio }\end{array}$ & Coeff. \\
\hline $\begin{array}{l}\text { Hybridit } \\
\text { y }\end{array}$ & $\begin{array}{l}1.402^{\dagger} \\
(0.204)\end{array}$ & $\begin{array}{c}0.338^{\dagger} \\
(0.146)\end{array}$ & $\begin{array}{l}3.516^{\dagger} \\
(0.738\end{array}$ & $\begin{array}{l}1.257^{\dagger} \\
(0.210)\end{array}$ & & & & \\
\hline $\begin{array}{l}\text { Hybrid } \\
\text { Polyarc } \\
\text { hy }\end{array}$ & & & & & $\begin{array}{l}2.448^{\dagger} \\
(0.399)\end{array}$ & $\begin{array}{c}0.895^{\dagger} \\
(0.163)\end{array}$ & $\begin{array}{l}2.351^{\dagger} \\
(0.551)\end{array}$ & $\begin{array}{c}0.855^{\dagger} \\
(0.234)\end{array}$ \\
\hline $\mathrm{HDI}$ & & & $\begin{array}{c}30.086 \\
(16.10 \\
)\end{array}$ & $\begin{array}{l}3.404^{\dagger} \\
(0.535)\end{array}$ & & & $\begin{array}{c}20.663^{\dagger} \\
(10.818 \\
)\end{array}$ & $\begin{array}{l}3.028^{\dagger} \\
(0.523)\end{array}$ \\
\hline $\begin{array}{l}\text { Change } \\
\text { GDP }\end{array}$ & & & $\begin{array}{l}0.002^{\dagger} \\
(0.004\end{array}$ & $\begin{array}{l}-6.077^{\dagger} \\
(1.688)\end{array}$ & & & $\begin{array}{c}0.002^{\dagger} \\
(0.004)\end{array}$ & $\begin{array}{l}-6.095^{\dagger} \\
(1.677)\end{array}$ \\
\hline Urban & & & $\begin{array}{c}0.134 \dagger \\
(0.059\end{array}$ & $\begin{array}{c}-2.012^{\dagger} \\
(0.438)\end{array}$ & & & $\begin{array}{c}0.142^{\dagger} \\
(0.062)\end{array}$ & $\begin{array}{c}-1.953^{\dagger} \\
(0.434)\end{array}$ \\
\hline Trade & & & $\begin{array}{c}0.012^{\dagger} \\
(0.008\end{array}$ & $\begin{array}{c}-4.426^{\dagger} \\
(0.663)\end{array}$ & & & $\begin{array}{c}0.026^{\dagger} \\
(0.017)\end{array}$ & $\begin{array}{c}-3.653^{\dagger} \\
(0.643)\end{array}$ \\
\hline Internet & & & $\begin{array}{r}1.142 \\
(0.435\end{array}$ & $\begin{array}{c}0.133 \\
(0.382)\end{array}$ & & & $\begin{array}{c}1.252 \\
(0.478)\end{array}$ & $\begin{array}{c}0.225 \\
(0.382)\end{array}$ \\
\hline KOF & & & $\begin{array}{r}4.786 \\
(2.732 \\
\end{array}$ & $\begin{array}{c}1.566 \\
(0.571)\end{array}$ & & & $\begin{array}{l}2.695^{x} \\
(1.511)\end{array}$ & $\begin{array}{c}0.991^{*} \\
(0.561)\end{array}$ \\
\hline GDP & & & $\begin{array}{r}0.296 \\
0.186\end{array}$ & $\begin{array}{l}-1.216 \\
(0.627)\end{array}$ & & & $\begin{array}{c}0.290 \\
(0.186)\end{array}$ & $\begin{array}{l}-1.239 \\
(0.642)\end{array}$ \\
\hline Mineral & & & $\begin{array}{r}1.402 \\
(0.552\end{array}$ & $\begin{array}{c}0.338 \\
(0.394)\end{array}$ & & & $\begin{array}{c}2.015 \\
(0.820)\end{array}$ & $\begin{array}{c}0.701 \\
(0.407)\end{array}$ \\
\hline $\mathrm{N}$ & & & & & & & & \\
\hline
\end{tabular}

Where $P>|z|$ is $\leq 0.001^{\dagger}, \leq 0.005^{\ddagger} \leq 0.05$

Other unmentioned variables included in the regression model include a control for the post-cold war period, a control for whether the city served as a capital for the country, and controls for countries which included more than one city within the dataset.

The results from these two logistic regression models are very similar to that of the negative-binomial models discussed previously. When considering both statistical significances, and how that statistical significance translates to real significance, regime hybridity is second in importance only to HDI and is significant even when HDI is taken into account. Translating the statistical findings above into what it means for the measure, as a regime moves from fully democratic or autocratic to fully hybrid, that there is an increase of approximately 35 percent in the likelihood of an event occurring in a given year. This increase can be seen graphically below in Graph 7 . 


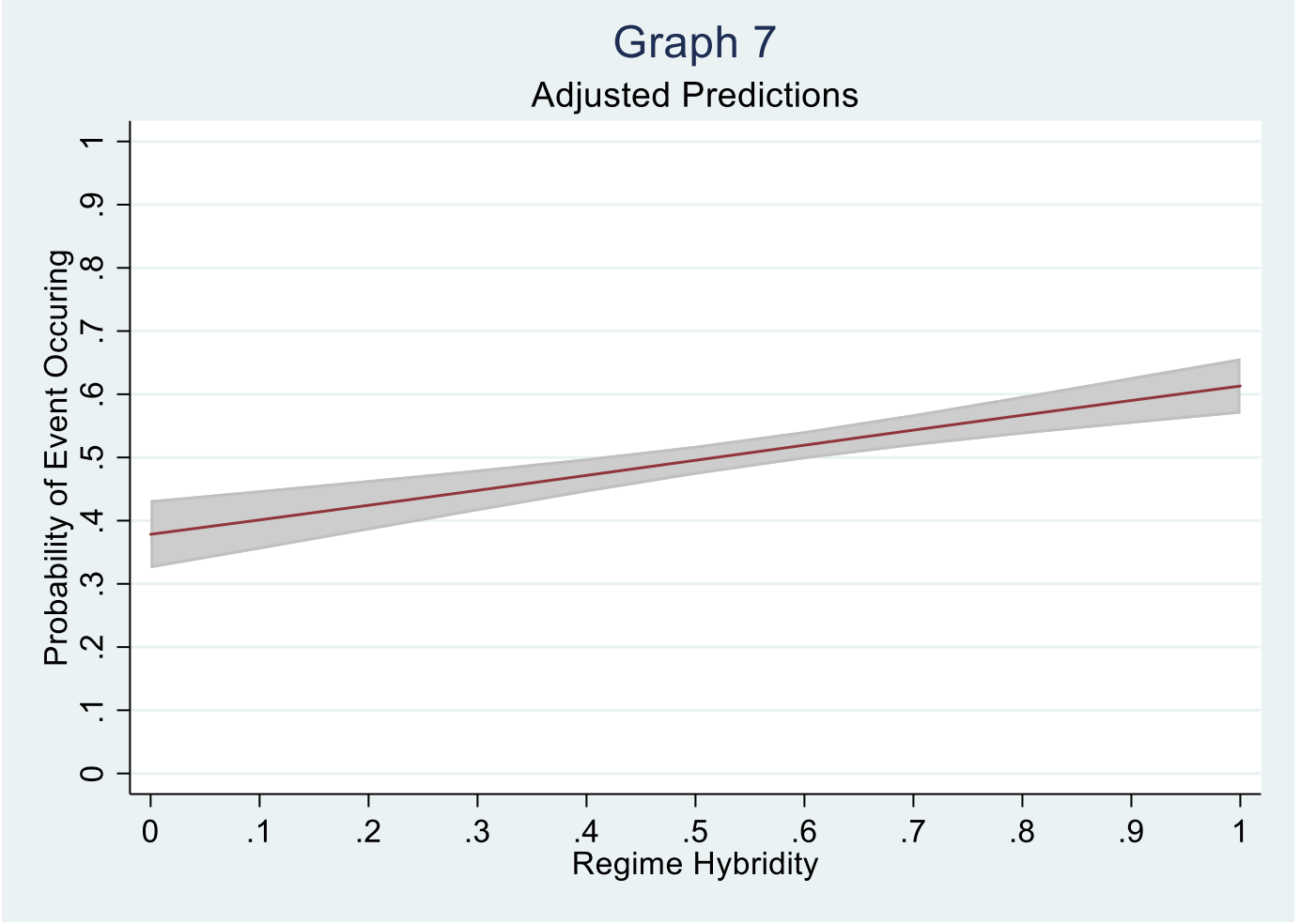

The conclusions to be drawn from the statistical analysis part of this paper is that there is a correlation which exists between regime hybridity and political disorder events. However, it is not affirmed the exact nature of the relationship. While this paper asserts that the relationship exists with regime hybridity being the influencer of political disorder events occurring, it is not possible with statistical methods to verify this. Therefore, this paper will now turn to the content analysis from the case study. 


\section{ALGERIAN CONTENT ANALYSIS}

Before turning to focus on the case study and the history of Algeria it is prudent to give answer to two obvious criticisms that could be leveled against this case study.

The first of these criticisms is that the year selected, 1997, was in many ways an easy test year for this project. This argument is essentially that because 1997 saw elections, that the case study is biased in favor of finding positive results. The second criticism is that the events seen in 1997 were primarily a continuation of the violence from the civil war, which in turn can be seen as caused by regime closure. Through this logic the conclusion is that the violence seen in Algeria in 1997 was a result of closure and not of hybridity.

The year 1997 was selected as the focus of the study prior to delving into the case and familiarizing with the events occurring in that year. It was unknown that the elections were occurring in 1997 when the decision was made to focus on this case. In selecting the year for the study two criteria were sought, first that there was a high number of events in that year, and second that Algiers was a hybrid regime in that year. 1997 saw both criteria meet and was therefore selected in a Lieberman style case study selection. Finally, there is strong evidence that some of the events in 1997 were as a result of the elections and 
organized by political parties, which would alleviate concerns surrounding the second aforementioned criticism.

\section{The Modern History of Algeria}

Algeria is a former colony of France, and even today maintains a close but tumultuous relationship with France. Upon being granted independence from France in 1962, Algeria was established as a secular democracy, though in practice the military was given a vast amount of influence and control, thus placing them as a hybrid regime (Mundy 2015, p. 31). This government remained in place until 1991. During the elections of 1991, the Islamic Salvation Front (FIS) obtained a majority vote share (Mundy 2015, p. 34). However, the governing political party at the time was afraid of what would happen when the FIS won the election (as they seemed poised to do) and seized power for itself through a military coup, which is why Algeria swung closer to an authoritarian regime from 1992-1994. It is important to note that despite the government halting all elections and seizing power for their party the National Liberation Front, opposition parties did not vanish. Instead, opposition parties began organizing to try to force the government to hold elections again (Mundy 2015, p. 62). The FIS splintered into many political parties, and their presence gave credence to the formation of other opposition parties during the interim. These opposition parties adopted several strategies to try to aid in ending the violence, and in forcing the government to hold elections. Some of these parties focused on getting the attention of France, the former colonial ruler of Algeria. This effort was made in an attempt to get France to intervene and was primarily utilized due to the high 
number of refugees who fled to France during the conflict, citing fear of violence from both the government and the insurgents. Other actors focused on drawing in the West; this was especially true of groups which focused their attention on lobbying NGO's like amnesty international. Other actors decided that the only way to achieve success against the government was to force action via protests and violence. Observers have sometimes described the period from 1991 to 1997 as a civil war in Algeria, with the government fighting against the Berbers and Islamic guerrilla fighters (Mundy 2015, p. 44). 1997, however, saw a turning point in this conflict, with the government relenting and opting to hold elections, though having barred any parties with religious affiliations (Mundy 2015, p. 81). Two types of violence are discernable in 1997, violence concentrated around the two elections held that year, and continued violence from the previous 6 years of fighting between the government and insurgents. Despite the reinstallation of supposedly democratic elections, most resistance fighters in the Armed Islamic Group (GIA) and the Islamic Salvation Army (SIA) did not lay down their weapons. ${ }^{10}$ However, there was also violence and protest corresponding to the two election days that took place in 1997. Both the parliamentary election which took place in June of 1997 and the local elections which took place in October of 1997 were regarded with deep skepticism both by opposition parties and by foreign observers. The main party for the government of Algeria in 1997, the National Democratic Rally, was able to win the majority of seats in both the

\footnotetext{
${ }^{10}$ Though, after the parliamentary elections, the SIA opted to attempt to gain a truce with the government citing the return of elections. It is, even years later, unclear whether the truce was honored by both sides.
} 
parliament and local elections. In both cases, the pro-government party the National Liberation Front, which had been the party of the government before the 1992 coup, was awarded the second highest number of seats. These two progovernment parties were followed by a handful of opposition parties which were made up of many different groups, ideologically and culturally. These groups ranged from parties which in all but name were Islamic in orientation, to communist worker parties, to labor parties, and a culturally Berber party (which held a strong secularist view). In the days, and weeks after the results of both the parliamentary and the local elections of 1997, this handful of parties held joint protests, accusing the government of election fraud, and pressuring for a recount or new elections. This was also accompanied by an increase in violence in Algiers following both of these elections, though no reports were made of any attacks taking place on either election day.

\section{Content Analysis}

The NexisUni archival search returned 800 total articles from the search function utilized. Of these 800 articles, only 540 articles were related to episodic political disorder related to the city of Algiers in 1997. While nearly all of the 800 articles made at least an indirect mention to opposition parties or Islamic parties, the bar for this case study is set higher. Thus, there needed to be a direct mention of one of the opposition parties operating in Algeria in 1997. These opposition parties are the Islamic Salvation Front, the Assembly for Culture and Democracy (RCD), the Front of Socialist Forces (FSS), the Rally for Culture and Democracy, and the Movement for Peaceful Society. Excluded from this 
grouping of opposition parties is the GIA and the SIA, both of which are seen as either a militant group or a terrorist organization by Algeria and many foreign countries. Though it is crucial to understand that these two organizations were founded as splinter groups from the FIS following the arrest of key leaders in 1991. A division along the lines of what tactics to employ left the GIA and SIA splintered from the FIS, as the GIA and the SIA began a campaign of violence aimed at toppling the government. There is not a single article in the 540 which does not give mention to the GIA or the SIA, either by name directly or through the much-used term "Islamic militants," which was often utilized when the attack was not clearly within the operating territory of either group.

While the presence of the GIA is positive evidence of the mechanism of opposition party presence in increasing propensity for political disorder, there are some overall concerns with placing too much emphasis on this particular piece of evidence alone. While it is true that the GIA was unquestionably formed from the FIS and operated in the areas where they most heavily garnered support in the 1991 election ("100 Algerians Are Killed In 48 Hours of Violence”, 1997). The GIA also show signs befitting the alternative hypotheses. Their main location or head of the operation was in a "mountainous region of Algeria," thus implying that they choose it for its remote local befitting the alternative hypothesis $\mathrm{H}_{6}$ ("Algeria's Agony" 1997). Additionally, while their initial violence may have only been to bring about the return of elections, they later continued to use violence for other means. For example, there are accounts of the GIA taking the prettiest women from the pro-government villages that they raided as sex slaves (Ibrahim 1997), 
thus validating the hypothesis $\mathrm{H}_{4}$. It is also true that their cause for fighting represents both the lack of political opportunity and access to power, but also a religious overture, as they were fighting in part to allow Islam into the Algerian government (Cohen 1997, "A Chance to Try to End an Agony"). These considerations also validate $\mathrm{H}_{3}$ and $\mathrm{H}_{5}$. So, while the GIA definitively validates the hypothesis and causal mechanism proposed by this paper, it does an equally good job of supporting the alternative hypotheses.

Of the 540 articles relevant to this content analysis, 369 directly mentioned opposition parties by name when discussing political disorder events - leaving 171 articles which did not directly mention an opposition party.

The FIS winning a majority of votes in the 1991 election was what caused the period of violence from 1991-1997. Despite the government banning the party and targeting its leaders, the FIS continued to operate within Algeria. The FIS did not maintain cohesion, though, as mentioned above, a group of members splintered off and focused on violence as the means of gaining power; others, however, decided to pursue the matters more peacefully (Cohen 1997, "Despite Freeing of a Militant, No Letup In Algerian Strife"). As mentioned above, 369 of the returned 540 articles or nearly seventy percent of the articles published during this time period, gave explicit mention to an opposition party.

One crucial piece of evidence that stands out from the content analysis is the attention paid to Abbassi Madani, who was the leader of the FIS during the 1991 elections (Cohen 1997, “Algeria's Main Rebel Faction Takes Risk and Calls Truce"). Imprisoned from 1991 to 1997 Madani maintained the position or 
appearance as the leader for the opposition. In 1997, to bring an end to the violence, the government released Madani from prison. Madani's release from prison was very clearly viewed by the news articles as an effort made by the government to bring the violence that had been occurring in the country for six years to an end. Madani returned to his position at the head of the FIS and called for an end to the violence and the reestablishment of elections ("Algerian Islamic Activist Put Under House Arrest" 1997). Madani continues today to be the leader of the FIS in Algeria. The fact that these members choose to remain in the open, and to confront the government more peacefully, makes this evidence stronger in the sense that it does not sit with $\mathrm{H}_{4}$ or $\mathrm{H}_{6}$, though $\mathrm{H}_{3}$ and $\mathrm{H}_{8}$, grievances and cultural motivations may still be a consideration.

Additionally, a new political party was formed from a group of former FIS members, calling itself the Movement of Society for Peace ("Algerian Vote Nears, Democracy in Ruins" 1997). It focused on appealing internationally to France and the United States to apply pressure to Algeria to end the violence and allow the return of elections. Similarly, to the main body of the FIS, it did not advocate for violence as a means to an end. Thus again, this evidence is marginally stronger than that of the FIS involvement in that overarching cultural motivations are not present in the MSP to the same degree as they were in the FIS. The FIS specifically wanted a government based on the Quran; the MSP did not call for those measures to the same degree ("7 Moderates Appointed to Algerian Government" 1997). This difference can be seen in the diverse strategies employed in the 1997 elections. The MSP was initially called the Hamas party, 
but they opted to change their name to the MSP following the ban on religious parties. In contrast, the FIS opted to boycott the elections citing the ban as undemocratic and unfair. However, the MSP as evidence still fails to overcome the same grievance issue.

The news articles from this content analysis were also quick to lay blame for the violence occurring in the country directly at the feet of the FIS. Throughout all of the articles explicitly focused on the violence from this period, one phrase is ubiquitous; "Islamic militants have been waging an insurgency against the military-backed government since 1992 when elections that the fundamentalist Islamic Salvation Front was poised to win were canceled." This exact phrase can be seen throughout a lot of the articles within the sample, and even more, can be seen when including articles that have slightly altered the text. This phrase is usually either preceded or succeeded by a figure about the death toll from the fighting. This seems to be clear evidence that the authors of these news articles are at least attributing part of the blame for the ongoing violence in Algeria to the FIS.

Furthermore, there are two sets of articles corresponding to the two postelection periods in 1997, where several of the opposition parties are cited as instigating and organizing demonstrations, protests, riots, and walk-outs, to change the election results. One article specifically mentions a march on the capital which was organized and joined by, five of the opposition parties, and two of the parties in the governing coalition (Khiari 1997, "Opposition readies for new election protest"). There is clear evidence throughout these articles that the 
opposition parties are seen as the perpetrators, rather than the victims, of these political disorder events.

Finally, the goals of these parties are apparent; there is little confusion about their interest in terms of organizing these events. For the militant groups, the goal is access to power; they want to be the group that is in control of the country, as evinced by the myriad of references to the insurgent's goal of 'toppling' the regime. For the FIS the goal of their protest and actions was initially to force the government to hold elections again. However, this goal changed once the government banned religious, political parties from participation in the elections. Once the ban occurred, the FIS participated in these events in order to enact policy change, the lifting of the ban on participation. Finally, the opposition parties were concerned with forcing the government to either rehost the elections which were viewed as fraudulent or to initiate a recount which could confirm or dispel the view that the elections were rigged by the government.

The overall evidence from the content analysis of the NexisUni articles reveals strong evidence for the hypothesized causal mechanism of opposition parties in hybrid regimes producing an increase in propensity for political violence. However, it also failed to reject the other possible hypotheses entirely and specifically failed to account for the grievance hypothesis of political disorder. It is worth noting that there are some reasons to be skeptical in thinking that this case study has presented the most reliable possible evidence. First, the NexisUni is not necessarily the best choice in new sources for understanding Algerian events; perhaps local newspapers which would write in Arabic would 
have yielded different results. Second, utilizing news media to understand the events occurring in 1997 primarily from the opposition may not be ideal. The Algerian government in 1997 was cited throughout the news articles as restricting the freedom of the press in the country throughout the year as they wished to keep information about the attacks to a minimum. Thus, it may have been difficult for these parties to get information about what they were doing out to the broader world. Therefore, accessing party archival material from the period would have been another strategy that could be applicable. Also, attempting interviews with party leaders or members from the time could be a strategy employed to find evidence. However, neither of these were chosen due primarily to the language barrier. Finally, in attempting to form a better view of the hypothesized relationship, it would be ideal for a comparison to be formed between a hybrid regime, and a non-hybrid regime, however space limitations made that impossible for this project. 


\section{DISCUSSION AND CONCLUSION}

When examining the summation of the evidence, and the results from the case study, and the statistical analysis, it seems that there is a strong indication that the hypothesized relationship and the outlined causal mechanism are both supported.

What remains unanswered though, is the rejection of all of the alternative hypotheses, in particular, $\mathrm{H}_{3}$ the Grievance theory, and $\mathrm{H}_{8}$ the social identity theory, both are unable to be disproven or rejected. Additional work aimed directly at contesting either of these alternative explanations would likely yield more concrete evidence against them. For example, focusing more specifically on countries where data is available about ethnoreligious fractionalization and access to power is available would allow for the Grievance theory to better be tested. Alternatively, employing more than one case in the case study section may allow for the religious and social identity argument to become weakened, as evidence similar social identities in non-hybrid regimes not resulting in increases in political disorder events would be strong evidence against this theory. Unfortunately, both of these methods are outside of the scope of this particular project.

It is prudent to examine the results from this study with two frames of focus, first, what does this mean in terms of scholarship, and further studying of 
this area of focus, and second, what policy recommendations, and other realworld insights can be gleaned.

One important scholarly vein that has been revealed by this work is attempting to understand how hybrid regimes can survive despite being seemingly burdened by institutions which invite political disorder into society. Hybrid regimes experience more disorder events which threaten the very survival of the regime, yet they seem (at least some hybrid regimes) to remain stable. Algeria, for example, endured a six-plus year civil war which saw around 100,000 Algerian civilians killed, (some estimates place the number over 100,000 some under 100,000 ) yet at no point in this bloody conflict was the government seemingly in fear of losing their power. Some evidence of why this may be is revealed in the content analysis, as some locals when asked about the violence by these journalists explained that the violence was being used by the government in order to give evidence for their continued control of power. It is natural to reason that so long as there is a crisis, the government can easily dissuade their populace from seeking any form of transition of power, at least until the crisis is over.

Furthermore, there were claims that the violence was being used to keep the populace aligned against the Islamic insurgents. This line of thinking was especially avowed by those individuals who suggested that the government was behind at least some of the massacres. Thus, a significant line of potential future research should be aimed at addressing the question of how hybrid regimes survive. 
Another very intriguing line of scholarly inquiry that is made clear by this research is the distinction of opposition. In the Algerian case, the decision was made to focus solely on formal organized political opposition; there is indeed an argument which could be made that the insurgent organization is equally important. It seems very clear that future inquiries could focus more heavily on comparing the two strategies. While Algeria simultaneously hosted both formal political opposition and violent insurgent opposition, other hybrid regimes undoubtedly only played host to one of these types of oppositions. A comparison of the efficacy and results of these two different types of opposition may lead to a clearer understanding of what type of opposition hybrid regimes can deal with, and what type of opposition they are unable to survive.

Switching to focus on how this affects the practitioners of political science, legislators, Nongovernmental Organization workers, and other such individuals, there are some important findings. The first of these is the recognition that hybrid regimes are a distinct, and at least for now, permanent regime type in the international system. It is no longer useful to view these states as democracies not yet arrived. By viewing these regimes as independent typologies, there could be better policies aimed at interacting with these regimes.

Furthermore, understanding how the institutions within a hybrid regime lead to their increased volatility may help policymakers seeking to help end the violence currently ongoing in hybrid regimes around the globe. By understanding what institutions are giving rise to the violence that is permeating these societies, there could be greater attention paid on how to fix the violence. 
Finally, there can surely be some insight drawn from the Algerian case. There was a plethora of media attention given to Algeria and the violence taking place there, with almost one and a half news articles being published daily throughout 1997. There was no outside intervention to aid the civilians in Algeria. Despite calls for help, both from civilians and the opposition parties within Algeria, and from the refugees outside of Algeria, no help was given. The United Nations and Europe failed to answer the call for help, respecting the sovereignty of Algeria at the cost of tens of thousands of lives. It seems that if outside help had come these lives could have been saved; this is especially true if adopting the stance that the government was at least partially responsible for perpetrating the violence, as many within and outside of Algeria did at the time. While the government continually reassured the West that the conflict was on-going to protect secular democracy, it is apparent that the government was simultaneously violating these same democratic principles it claimed to be protecting.

In summation, this project displayed strong evidence, both statistically, and qualitatively that the theory within this paper is supported. This hypothesis stated at the beginning of this paper was, as regime hybridity increases occurrences of political disorder will also increase. This paper argues that that this hypothesized increase is due both to lack the institutions that democracies and authoritarian regimes enjoy that hamper the collective action problem, and also because hybrid regimes have institutions which aid in overcoming the collective action problem. Three institutions were highlighted as potentially being 
responsible for this, the media environment, the judiciary, and opposition parties.

Ultimately this paper focused its attention on opposition parties and found a strong connection between their presence and the occurrence of political disorder. 


\section{REFERENCES}

Aristotle trans by Barket, E. (1958). Politics (Vol. 3).

Barnes, W. A. (1998). Incomplete democracy in Central America: polarization and voter turnout in Nicaragua and El Salvador. Journal of Interamerican Studies and World Affairs, 40(3), 63-101.

Barrie, C. (2017). The contentious politics of nationalism and the anti-naturalization campaign in Tunisia, 1932-1933. Nations and Nationalism, 23(4), 707-725. doi:10.1111/nana.12254

Bennett, W. L., \& Segerberg, A. (2012). The logic of connective action: Digital media and the personalization of contentious politics. Information, Communication \& Society, 15(5), 739-768.

Bogaards, M. (2009). How to classify hybrid regimes? Defective democracy and electoral authoritarianism. Democratization, 16(2), 399-423.

Brownlee, J. (2009). Portents of pluralism: How hybrid regimes affect democratic transitions. American Journal of Political Science, 53(3), 515-532.

Buhaug, H., \& Gates, S. (2002). The geography of civil war. Journal of Peace Research, 39(4), 417-433.

Bunce, V. J., \& Wolchik, S. L. (2006). International diffusion and postcommunist electoral revolutions. Communist and Post-Communist Studies, 39(3), 283304.

Burke, M. B., Miguel, E., Satyanath, S., Dykema, J. A., \& Lobell, D. B. (2009). Warming increases the risk of civil war in Africa. Proceedings of the National Academy of Sciences, 106(49), 20670-20674. 
Collier, D., \& Adcock, R. (1999). Democracy and dichotomies: A pragmatic approach to choices about concepts. Annual Review of Political Science, 2(1), 537-565.

Collier, D., \& Levitsky, S. (1997). Democracy with adjectives: Conceptual innovation in comparative research. World Politics, 49(3), 430-451.

Collier, P., \& Hoeffler, A. (2004). Greed and grievance in civil war. Oxford economic papers, 56(4), 563-595.

Collier, P., \& Sambanis, N. (2005). Understanding Civil War (Volume 1: Africa) Evidence and Analysis: The World Bank.

Diamond, L. (2015). Hybrid regimes. In Search of Democracy (pp. 163-175): Routledge.

Donno, D. (2013). Elections and democratization in authoritarian regimes. American Journal of Political Science, 57(3), 703-716.

Eder, M., \& Öz, O. z. (2017). Spatialities of contentious politics: The case of Istanbul's Beşiktaş neighborhood, çArşı footfall fandom and Gezi. Political geography, 61, 57-66. doi:10.1016/j.polgeo.2017.06.008

Ekman, J. (2009). Political participation and regime stability: A framework for analyzing hybrid regimes. International Political Science Review, 30(1), 731.

Fearon, J. D., \& Laitin, D. D. (2003). Ethnicity, insurgency, and civil war. American political science review, 97(1), 75-90.

Fukuyama, F. (1992). The end of history (pp. 702-6). New York: Free Press.

Garretón, M. A. (2003). Incomplete democracy. Political Democratization in Chile andLatin.

Geddes, B. (2018). Why dictators hold semi-competitive elections and encourage the use of semi-independent courts: a comment on Thornhill and 
Smirnova's "litigation and political transformation". Theory and Society, 47(5), 595-601.

Gilbert, L., \& Mohseni, P. (2011). Beyond authoritarianism: The conceptualization of hybrid regimes. Studies in Comparative International Development, $46(3), 270$.

Goldsmith, A. A. (2010). Mixed regimes and political violence in Africa. The Journal of Modern African Studies, 48(3), 413-433.

Greene, S. A. (2014). Moscow in movement: power and opposition in Putin's Russia: Stanford University Press.

Hamot, G. E. (1998). A Case of Teacher Education Reform in Poland's Transitional Democracy: " The School in a Democratic Society." European Education, $30(2), 5-24$.

Hazbun, W. (2016). Assembling security in a 'weak state:' the contentious politics of plural governance in Lebanon since 2005. Third World Quarterly, 37(6), 1053-1070. doi:10.1080/01436597.2015.1110016

Hegre, H., Ellingsen, T., Gleditsch, N. P., \& Gates, S. (2001). Towards a democratic civil peace? Opportunity, grievance, and civil war, 1816-1992. American Political Science Review, 95(1), 33-48.

Hegre, H., Østby, G., \& Raleigh, C. (2009). Poverty and civil war events: A disaggregated study of Liberia. Journal of Conflict Resolution, 53(4), 598623.

Howard, M. M., \& Roessler, P. G. (2006). Liberalizing electoral outcomes in competitive authoritarian regimes. American Journal of Political Science, 50(2), 365-381.

Humphreys, M. (2005). Natural resources, conflict, and conflict resolution: Uncovering the mechanisms. Journal of Conflict Resolution, 49(4), 508537. 
Huntington, S. P. (1993). The third wave: Democratization in the late twentieth century (Vol. 4): University of Oklahoma Press.

Johnston, H., \& Alimi, E. Y. (2012). Primary Frameworks, Keying and the Dynamics of Contentious Politics: The Islamization of the Chechen and Palestinian National Movements. Political Studies, 60(3), 603-620. doi:10.1111/j.1467-9248.2011.00927.x

Karl, T. L. (1995). The hybrid regimes of Central America. Journal of Democracy, $6(3), 72-86$.

Leung, D. K. K. (2015). Alternative Internet Radio, Press Freedom and Contentious Politics in Hong Kong, 2004-2014. Javnost - The Public, 22(2), 196-212. doi:10.1080/13183222.2015.1041229

Levitsky, S., \& Way, L. (2002). The rise of competitive authoritarianism. Journal of Democracy, 13(2), 51-65.

Levitsky, S., \& Way, L. A. (2010). Competitive Authoritarianism: Hybrid regimes after the Cold War: Cambridge University Press.

Lieberman, E. S. (2005). Nested analysis as a mixed-method strategy for comparative research. American political science review, 99(3), 435-452.

Lynch, M. (2014). The Arab uprisings explained: New contentious politics in the Middle East: Columbia University Press.

Mew, S. (2013). Contentious Politics: Financial Crisis, Political-Economic Conflict, and Collective Struggles. Social Justice, 39(1 (127)), 99-114.

Morlino, L. (2009). Are there hybrid regimes? Or are they just an optical illusion? European Political Science Review, 1(2), 273-296.

O'donnell, G., Schmitter, P. C., \& Arnson, C. J. (2013). Transitions from authoritarian rule: Tentative conclusions about uncertain democracies: JHU Press.

O'donell, G. A. (1994). Delegative democracy. Journal of Democracy, 5(1), 55-69. 
Olzak, S. (2011). Does globalization breed ethnic discontent? Journal of Conflict Resolution, 55(1), 3-32.

Ottaway, M. (2003). Democracy challenged. The rise of Semi-authoritarianism. Washington, DC: Carnegie Endowment for International Peace.

Ottaway, M. (2013). Democracy challenged: The rise of semi-authoritarianism: Carnegie Endowment.

Raleigh, C., \& Hegre, H. (2009). Population size, concentration, and civil war. A geographically disaggregated analysis. Political Geography, 28(4), 224238.

Robertson, G. B. (2010). The politics of protest in hybrid regimes: Managing Dissent in post-communist Russia: Cambridge University Press.

Ross, M. (2006). A closer look at oil, diamonds, and civil war. Annu. Rev. Polit. Sci., 9, 265-300.

Ross, M. L. (2004). How do natural resources influence civil war? Evidence from thirteen cases. International organization, 58(1), 35-67.

Salehyan, I., \& Gleditsch, K. S. (2006). Refugees and the spread of civil war. International organization, 60(2), 335-366.

Samuel, P. (1996). Huntington, 1991. The clash of civilizations and the remaking of world order, 249-273.

Schedler, A. (2002). The menu of manipulation. Journal of Democracy, 13(2), 3650.

Schedler, A. (2006). Electoral Authoritarianism: The dynamics of unfree competition.

Schedler, A. (2015). Electoral authoritarianism. Emerging trends in the social and behavioral sciences: An interdisciplinary, searchable, and linkable resource, 1-16. 
Schumpeter, J. A. (1942). Socialism, capitalism and democracy: Harper and Brothers.

Shadmehr, M. (2014). Mobilization, Repression, and Revolution: Grievances and Opportunities in Contentious Politics. The Journal of Politics, 76(3), 621635. doi:10.1017/s0022381614000267

Simmons, C. S. (2005). Territorializing land conflict: Space, place, and contentious politics in the Brazilian Amazon. GeoJournal, 64(4), 307-317.

Thies, C. G. (2010). Of rulers, rebels, and revenue: State capacity, civil war onset, and primary commodities. Journal of Peace Research, 47(3), 321-332.

Tilly, C. (1978). Power in Movement: Social Movements and Contentious Politics. In: Reading, MA: Addison-Wesley.

Tilly, C., \& Tarrow, S. G. (2015). Contentious politics: Oxford University Press.

Urdal, H., \& Hoelscher, K. (2012). Explaining urban social disorder and violence: An empirical study of event data from Asian and sub-Saharan African cities. International Interactions, 38(4), 512-528.

Wheatley, J., \& Zürcher, C. (2008). On the Origin and Consolidation of Hybrid regimes. Taiwan Journal of Democracy, 4(1), 1-31.

Wigell, M. (2008). Mapping 'hybrid regimes': Regime types and concepts in comparative politics. Democratisation, 15(2), 230-250.

Wood, E. J. (2003). Insurgent collective action and civil war in El Salvador: Cambridge University Press.

Zakaria, F. (1997). The rise of illiberal democracy. Foreign Aff., 76, 22.

Zemni, S. (2017). The Tunisian Revolution: Neoliberalism, Urban Contentious Politics and the Right to the City. International Journal of Urban and Regional Research, 41(1), 70-83. doi:10.1111/1468-2427.12384 


\section{APPENDIX}

\section{Figure 1}

\section{Alternative Hypothesis}

$\mathrm{H}_{3}$ : If access to political power decreases along ethnic, or religious lines, then occurrences of political disorder will increase.

$\mathrm{H}_{4}$ : If economic inequality increases, then occurrences of political disorder will increase.

$\mathrm{H}_{5}$ : If the presence of loot-able resources within a country increases, then occurrences of political disorder will increase.

$\mathrm{H}_{6}$ : If a countries exportation of goods increases, then occurrences of political disorder will decrease.

$\mathrm{H}_{7}$ : If a countries globalization increases, then occurrences of political disorder will decrease.

$\mathrm{H}_{8}$ : If religious, ethnic, or other social identities within a country encourage, or promotes contestation with the government, then occurrences of political disorder will increase.

$\mathrm{H}_{9}$ : If the conditions within a country allow groups to contest the states military capability, then occurrences of political disorder will increase. 


\section{CURRICULUM VITA}

NAME: Bryce Jamison Kleinsteuber

ADDRESS: Department of Politial Science

Ford Hall West Kentucky St,

University of Louisville

Louisville, KY 40208

DOB: $\quad$ Louisville, Kentucky - July 26, 1994

\section{EDUCATION}

\& TRAINING: $\quad$ B.A., Political Science

Univeristy of Louisville

2012-2015

\section{M.A., Political Science \\ University of Louisville}

2017-2019

PROFESSIONAL SOCIETIES:

Member of MENSA

Kentucky Political Science Association

Member of the Graduate Student Council

Midwest Political Science Association
Since 2004

Since 2016

Since 2017

Since 2018

\section{PUBLICATIONS:}

"Political Targeting and Value Application: The Effects of Framing Gay Rights Issues on Opinions among Blacks and Whites" Rhodebeck, Laurie, Gainous, Jason, Kleinsteuber, Bryce. 


\section{PRESENTATIONS:}

"Hybrid regimes and Political disorder: A multimethod approach to understanding Hybrid regime instability" Presented at Midwest Political Science Association 2019, Chicago, IL.

"Hybrid regimes and Political disorder: A multimethod approach to understanding Hybrid regime instability" Presented at Kentucky Political Science Association 2019, Louisville, KY.

"Controlling the Flow of Information: European Political Parties, State Type, and Electoral Success" Presented at Kentucky Political Science Association 2016, Berea, KY. 